\title{
ANTI-BLACK RACISM IN CHILD WELFARE
}

by

Ruth Naomi Damdar, BA, York University 2013, BSW, York University 2017

\author{
An MRP \\ Presented to Ryerson University \\ In partial fulfillment of the \\ Requirements for the degree of \\ Master of Social Work \\ in the program of \\ Social Work \\ Toronto, Ontario, Canada, 2018 \\ C _Ruth Naomi Damdar 2018
}




\section{AUTHOR'S DECLARATION FOR ELECTRONIC SUBMISSION OF A MRP}

I hereby declare that I am the sole author of this MRP. This is a true copy of the MRP, including any required final revisions.

I authorize Ryerson University to lend this MRP to other institutions or individuals for scholarly research.

I further authorize Ryerson University to reproduce this MRP by photocopying or by other means, in total or in part, at the request of other institutions or individuals for scholarly research.

I understand that my MRP may be made electronically available to the public. 


\author{
ABSTRACT \\ Anti-Black Racism in Child Welfare \\ Master of Social Work 2018 \\ Ruth Naomi Damdar \\ Program of Social Work \\ Ryerson University
}

Black children are over-represented in Toronto's Children's Aid Society (CAS). A variety of academic of literature points to racism, specifically anti-Black racism, as the reason for such high rates of apprehension of Black children. Indeed the Government of Ontario (2017) found the need for training on anti-Black racism to combat structural oppression. While the literature acknowledges that anti-Black racism is a major contributing factor to the overrepresentation of Black children in-care, there is a gap present about how, or if conversations about anti-Black racism are occurring within CAS. This study highlights the voices of three selfidentified critical frontline workers at CAS to better understand how and if conversations about anti-Black racism occur, as well as what kinds of barriers may exist to having such conversations within CAS. 
ACKNOWLEDGEMENTS: Thanks to my family for all their support throughout this process. 
DEDICATION: Dedicated to my research participants. Thank you for taking the time to participate in this research. 
TABLE OF CONTENTS

Chapter I: INTRODUCTION

Chapter II: LITERATURE REVIEW 4

$\begin{array}{ll}\text { Chapter III: THEORECTICAL FRAMEWORK } & 16\end{array}$

Chapter IV: METHODOLOGY 24

$\begin{array}{ll}\text { Chapter V: FINDINGS } & 30\end{array}$

$\begin{array}{ll}\text { Chapter VI: ANALYSIS } & 42\end{array}$

Chapter VII: IMPLICATIONS 51

$\begin{array}{ll}\text { Chapter: VIII: CONCLUSION } & 57\end{array}$

$\begin{array}{ll}\text { Appendices } & 58\end{array}$

$\begin{array}{ll}\text { Reference List } & 67\end{array}$ 


\section{LIST OF APPENDICES}

Page

$\begin{array}{lr}\text { Appendix A - Consent Forms } & 58\end{array}$

Appendix B - Recruitment Flyer $\quad 62$

Appendix C- Recruitment Facebook Post 63

$\begin{array}{ll}\text { Appendix D - Interview Questions } & 64\end{array}$

$\begin{array}{ll}\text { Appendix E - Demographic Questions } & 65\end{array}$

Appendix F - List of Counseling Resources $\quad 66$ 


\section{Chapter I: Introduction}

Childhood is socially constructed according to culture, discourses that reflect the sociopolitical and economic context of society at the time, and the simultaneous social construction of adulthood (Cech, 2010). In Canada, children started to be seen as vulnerable in the late 1800s and early 1900s, as childhood came to be seen as distinct from adulthood (Cech, 2010; Hick, 2009). During this time, the government became more involved in the issues of children (Hick, 2009). Various pieces of legislation were enacted, giving the government the ability to decide if parents were adequate caregivers in order to promote the best interests of the child (Hick, 2009). Thus, the government came to hold the power to remove children from their homes and place them in care (Hick, 2009). Ontario's child welfare system emerged in the early twentieth century, as increased industrialization and urbanization led to the marginalization of poor families, and children in such families came to be seen as vulnerable and in need of protection (Ontario Association of Children's Aid Societies, 2016). While Ontario's Children's Aid Societies (CAS) have helped many children, it is also important to note that these institutions have been entrenched in a long history of racism, sexism, colonialism and classism.

This means that there are many ways in which CAS is oppressive. The statistics from a report by the Toronto Star reveal that 41 percent of children in-care in Toronto's Children's Aid Society (CAS) are Black even though Black children make up approximately 8 percent of Toronto's population (Contenta, Monsebraaten, \& Rankin, 2014). This means that Black children are over-represented in Toronto's CAS. Literature by Clarke (2011) and Clarke (2012) highlight that it is largely impoverished Black mothers whose children are being apprehended. According to Wulczyn and Levry (2007) disproportionality refers to a population that is not 
proportionate to a reference population (as cited in Boyd, 2013, p. 16). Myers (2010) argues that in such a definition of disproportion, the reference population is considered the general child population, which often results in an inappropriate inflation of rates and disproportionality (as cited in Boyd, 2013, p.16). Instead, Myers (2010) argues that the reference population should be that which experiences a particular decision point in the child welfare system (Boyd, 2013, p. 16). According to this definition, we should compare the number of Black children taken into care with the total number of children taken into care at CAS. In the 2016-2017 year, 34\% of the children admitted to CAS Toronto were Black, while other populations admitted were significantly less (Children's Aid Society of Toronto, 2017). Thus, it is important to note that even following this definition, Black children still make up the largest percentage of children taken into care at CAS Toronto, while only accounting for $8 \%$ of Toronto's population.

Disparity, according to Wulczyn and Levry (2007), refers to a lack of equality (as cited in Boyd, 2013, p. 16). As such, Black children can be described as being disproportionate in the child welfare system because there is a disparity in how they are treated, in terms of reporting, substantiation of maltreatment claims, foster care placement, investigation, and exit (Boyd, 2013). Clearly, it is important to critically think about why Black children are over-represented at CAS and how CAS is responding to the issue of the over-representation of Black children incare.

I write on this topic as a racialized, cis gender female closely connected to critical approaches to social work and anti-oppression theory. My desire to focus on this topic is fuelled by many things. As a social work student, I have been at multiple social service agencies and have seen a lack of critical social work in many spaces, as well as how this may negatively impact clients. These experiences have driven me to get a better understanding of how anti- 
oppressive social workers may struggle to maintain their critical lens or work in critical ways in the field, thus reproducing harm. As such, I wanted to focus my research question on the frontline workers at CAS, especially as I felt that the responsibility for developing solutions to addressing over-representation should not solely fall on Black communities. I hoped that it would challenge CAS to think about what kinds of changes they could be responsible for in order to begin addressing over-representation.

Furthermore, I chose to focus on service providers rather than Black service users for other ethical reasons as well. According to Chilisa (2012)

a relational ethical framework invites researchers to see 'self' as a reflection of the researched 'Other,' to honour and respect the researched as one would wish for oneself, and to feel a belongingness to the research community without feeling threatened or diminished (as cited in Chilisa, 2017, p. 328).

This means that ethical research is connected to having a relationship with the community you are researching about. While I identify as racialized, I do not identify as Black. Further, the limited time for completing the MRP made it unlikely that I would be able to foster such a connection and belonging with research participants. Thus, I did not feel it would be ethical to enter Black communities to conduct research. I do, however, identify as belonging to the community of critical social workers, making it more ethical to conduct research with this community. 


\section{Chapter II: Literature Review}

In reviewing the literature around this topic, it is evident that multiple and interrelated themes have emerged throughout various pieces of literature. They are as follows:

\section{$\underline{\text { Immigration }}$}

Clarke (2011) notes that while Caribbean peoples have existed in Canada for hundreds of years, their political and material conditions have improved slightly, as many of their qualifications and experiences have been devalued, minimized (Clarke, 2011). Clarke (2011) notes that Caribbean people still experience racism and discrimination in multiple areas, including: education, housing, employment, and human services. This is supported by Maiter, Stalker, \& Alaggia, (2009) who note that when immigrants face a loss, a threat to, or a failure to gain resources after immigrating, it may increase the chances of child maltreatment. The findings reveal that migration means experiencing a loss of many important resources including: home, support and a decline in economic status (Maiter, Stalker, \& Alaggia, 2009).

Participants in their study also noted language struggles, the struggle to provide for a family, feeling betrayed or hopeless, financial struggles, and loneliness (Maiter, Stalker, \& Alaggia, 2009). Clarke (2011) adds to the conversation on how immigration impacts child welfare, noting that the issues faced by Afro-Caribbean families are often not recognized in child welfare. Maiter, Stalker, and Alaggia (2009) further add to this, noting that many immigrant parents in contact with CAS were unaware of why child welfare was involved with their families, as they had reached out to community agencies for support and this had resulted in CAS intervention.

\section{$\underline{\text { Poverty }}$}


Pelton (1978) argues that class is related to child abuse and that, as such, classlessness in relation to child abuse is a myth. Specifically, Pelton (1978) argues that, while child abuse happens across all socio-economic backgrounds, the likelihood of abuse increases for children living in impoverished families. This is supported by Miller, Cahn, and Orellana (2012) who note that many participants in their study identified poverty as a major factor to the disproportionate rates of Black children in the child welfare system. While their participants did not explicitly link abuse and neglect to racialized people, they noted that racialized people were more likely to live in poverty and that poverty is linked to the risk of child abuse (Miller, Cahn, \& Orellana, 2012). Boyd (2013) acknowledges that poverty impacts Black families, noting that Black children are over-represented among impoverished households and that this may result in greater exposure to risk factors associated with abuse. Boyd (2013) notes that both families and neighbourhoods experience poverty. In impoverished neighbourhoods Boyd (2013) notes that there are often high rates of unemployment, neighborhood violence, high rates of unemployment, high levels of crime, poor public schools etc. which may impact households that may not be individually poor. Indeed the lack of access to resources was also noted as a major contributing factor to the over-representation of racialized children in the child welfare system (Miller, Cahn, \& Orellana, 2012).

The literature reveals that additional perspectives around poverty exist. Jonson-Reid, Drake, \& Zhou (2013) conducted another study looking at race, kinds of neglect and poverty. They found that Black children were more often reported for both severe and basic needs neglect and that often these reports were substantiated (Jonson-Reid, Drake, \& Zhou, 2013). Further, according to Jonson-Reid, Drake, \& Zhou (2013), households in impoverished communities were more likely to be reported to child welfare than white children, even when family incomes 
were accounted for. Their findings, therefore, reveal hyper-surveillance of families living in poverty.

While some may argue that poverty is the major reason for the over-representation of Black children, this can also be called into question. The Ontario Association of Children's Aid Societies (2016) argues that there is no way to know exactly how many impoverished Black children are mistreated. Further, if poverty were the only cause of child abuse, impoverished white families should also be disproportionately represented in the child welfare system (Ontario Association of Children's Aid Societies, 2016). In their study, Wulczyn, Gibbons, Snowden, \& Lery (2013) found that rates of poverty were related to placement levels for white children, but that this relationship was not necessarily true for Black children. Thus, these pieces of literature question if poverty alone can account for the over-representation of Black children.

\section{$\underline{\text { Racism and Cultural Competency }}$}

Another major theme related to structural oppression is racism. Dorothy Roberts (2002) interviews Black service users and argues that racism exists systemically within the child welfare system. For Roberts (2002), this is why Black children are over-represented in the child welfare system, not poverty alone. This is supported by Mullings and Mullings-Lewis (2013) who describe that Black mothers are aware that both racist and sexist policies and programs exist within institutions and strategically parent their children as a result (Mullings \& Mullings-Lewis, 2013). The Ontario Association of Children's Aid Societies (2016) notes that racism exists in multiple layers of the child welfare system, including in the policies, law, frontline workers, and a culture of racism in the system. The Ontario Association of Children's Aid Societies (2016) notes that Black parents described that many mandated reporters, such as doctors and teachers, 
hold racial biases. This is supported by Miller, Cahn, \& Orellana (2012) who note that child welfare workers lacked the ability to engage with families of colour, including being able to engage with extended family members. They note that when racialized people engage in adverse behaviours, they are more likely to attract the attention of child welfare workers who are more likely to view those behaviours in negative ways (Miller, Cahn, \& Orellana, 2012).

Further, they note that the threat of harm is often ambiguous in child welfare and that, as such, many child welfare workers make personal judgments about threats that are based on race and class (Miller, Cahn, \& Orellana, 2012). They note that white standards of adequate care are often used, recognizing that workers at all levels of CAS hold racial biases that are rarely ever acknowledged (Miller, Cahn, \& Orellana, 2012). Without a clear definition of what constitutes harm, child welfare workers often speculate what may be happening in racialized families (Miller, Cahn, \& Orellana, 2012). Boyd (2013) supports this, recognizing that welfare workers may have bias based on racial stereotypes, which may be used by welfare workers who intend to protect kids from perceived threats. Cross (2008) notes that hesitation to confront ingrained prejudices, fears, and ignorance compound the disproportionality of Black children in care (as cited in Boyd, 2013, p.20).

Miller, Cahn, and Orellana (2012) note that cultural context was not considered when making decisions, highlighting a need for cultural competency. This is supported by Boyd (2013) who notes that the professionals' lack of cultural competency negatively impacts child welfare decision-making. While Boyd (2013); and Miller, Cahn, and Orellana (2012) seem to support the need for cultural competency in child welfare, Pon (2009) asks us to critically think about culturally competent practices. According to Pon (2009), cultural competency acts as a new form of racism because it leaves whiteness unmarked as the default norm. Further, it continues to 
'other' racialized groups, and reduce groups of people to a few fixed cultural traits, thereby essentializing them (Pon, 2009). Therefore, it maintains positivist, modern ideas about culture. This is supported by Gosine and Pon (2011) who note that child welfare agencies have cultural cliques where Black workers were only seen as Black and, as such, perceived as only being able to work with Black families. As such, they found that racism permeates the organizational culture of Children Aid Societies, often preventing racialized workers from attaining meaningful management/supervisory positions (Gosine \& Pon, 2011).

Clarke (2012) adds to this conversation by linking the experiences of racism, and gender and class oppression together. Specifically, Clarke (2012) found that Black mothers described two major themes: experiences related to being poor and Black and experiences of being poor Black mothers (Clarke, 2012, p. 233). In linking these themes together, Clarke (2012) is demonstrating how the concept of good mothers is a construction that is rooted in whiteness and class. Clarke (2012) is demonstrating how CAS is policing poor, Black mothers according to the white, middle-class constructions of mothering.

\section{Exalted Subjectivity Maintained Through Child Welfare}

The theme of exalted subjectivity emerges from pieces of literature by Thobani (2007); Pon, Gosine and Phillips (2011); and Pon, Phillips, Clarke, and Abdillahi (2017). Thobani (2007) links the history of Canada's overtly racist immigration laws to the child welfare system. Thobani (2007) argues that citizenship and immigration laws were major mediums through which white people attained the status of the exalted national subject (as cited in Pon, Gosine, \& Phillips, 2011, p.390). Immigration policies and practices were used to keep non-white, nonpreferred races out of the country. Thobani (2007) argues that non-preferred races of immigrants, especially Black women, were marked as intruders, inherently deviant, and as threats to the 
survival of the Canadian nation (as cited in Pon, Gosine, \& Phillips, 2011, p. 390). According to Thobani (2007), "women of the non-preferred races were constituted as morally degenerate, sexually depraved, and endowed with fecundity more animalistic than human" (as cited in Pon, Gosine, \& Phillips, 2011, p. 390).

Thobani (2007) notes that when the Canadian immigration point system was implemented, white supremacist discourses had already worked to construct non-whites as 'newcomers' or 'immigrants' even though Black peoples and Indigenous communities had already been in the settler nation for quite some time (as cited in Pon, Gosine, \& Phillips, 2011, p. 390). Clarke (2011) notes that in the 1960s racist immigration policies were curtailed and many racialized people were able to migrate to Canada. Thobani makes a link between citizenship, Canada's welfare state, and the child welfare system. Specifically, Thobani (2007) states that the "welfare system reinforced citizenship as the mechanism organizing the racial hierarchy of the settler society" (as cited in Pon, Gosine, \& Phillips, 2011, p.391). Thobani (2007) states that racialized immigrant families were not entitled to the benefits of the welfare state (as cited in Pon, Gosine, \& Phillips, 2011, p.391).

Further, Thobani (2007) notes that the expansion of the welfare state allowed the nation state to appear as if it truly wanted to represent all members of society (as cited in Pon, Gosine, \& Phillips, 2011, p. 391). Thobani (2007) argues that the welfare state played a central role in the upholding the master national narrative by working to construct the exalted nationals as kindhearted, caring, and compassionate (as cited in Pon, Gosine, \& Phillips, 2011, p. 391). This is central to the ontology of forgetting. Razack notes that Canada clearly has a violent history of racism, colonialism, and slavery, but an ontology of forgetting this history prevails, constructing Canada as a fair and tolerant society (as cited in Pon, Gosine, \& Phillips, 2011, p.388). 
In the 1960 s, the welfare state came to be represented by the child protection system (Pon, Gosine, \& Phillips, 2011). Where the child protection system came to represent Canada's welfare system, the workers within child welfare, particularly white women, came to embody and represent the benevolence of the Canadian nation due to Manicheanism spread through colonialism (Pon, Phillips, Clarke, \& Abdillahi, 2017). Thobani (2007) asserts that the post-war welfare state established a new significance of white women within the master narrative, so that white female social workers embodied feminized ideals of care and kindness reflected in the welfare state (as cited in Pon, Gosine, \& Phillips, 2011, p. 393).

As such, child welfare workers were seen to belong to the Canadian nation, worthy of the status of citizenship in Canada and gaining exalted subjectivity (Pon, Phillips, Clarke, \& Abdillahi, 2017). Therefore, the child welfare system continued to exclude the belonging of racialized groups and continued to marginalize them in society. Indeed Thobani (2007) supports this, saying that the construction of the exalted national defines, distinguishes and upholds the racialized Other and vice versa (as cited in Pon, Gosine, \& Phillips, 2011, p.392). As such, whiteness and white supremacy are further perpetuated. Colonial attitudes and beliefs about racialized groups of people are still perpetuated. Thobani (2007) further notes that the child welfare system continues to utilize this master narrative today (as cited in Pon, Gosine, \& Phillips, 2011, p.392). Particularly, child welfare workers are often seen as heroes saving Black children, enabling apprehension even when it may not be justified (Pon, Phillips, Clarke, \& Abdillahi, 2017).

Furthermore, Pon et al., (2017) note that even racialized child welfare workers may desire to benefit from the status of exalted national. Through the child welfare system, racialized workers may be participating in or desire to make claims to belonging to the Canadian nation 
(Pon et al, 2017). Thus, racialized workers may internalize the dominant culture, typical normative practices/procedures in child welfare and contribute to the national narrative as they seek acceptance (Pon et al., 2017).

\section{$\underline{\text { Structural Issues at CAS }}$}

Another important theme that emerged was whether or not CAS is able to adequately consider the structural oppression that clients face. Clarke (2011) found that workers said that race and class were not important considerations when they made assessments and conducted investigations. Workers felt there was a limited analysis of structural inequities, such as race, class, and gender and they felt that they could only address personal failings like "poor parenting" (Clarke, 2011). As such, many structural issues are individualized and become depoliticized.

This may be because of structural issues at CAS, including agency infrastructure. Agency infrastructure may include staffing patterns, caseload size, and the lack of ability to relate and find common traits between them and their clients may be related to challenges with potential to influence case outcomes for racialized families (Boyd, 2013). Organizational culture forms the environment where decisions are made (Boyd, 2013). According to Boyd (2013), institutional racism can contribute to organizational culture. Workers may make decisions based on fear of liability or fear of reprimands at work (Boyd, 2013). Thus, workers may remove children if they feel the agency will not support them, or that they would be punished for leaving children at home. Further, Anyon (2011) makes reference to other structural issues at CAS, such as the need for checks and balances built into the decision making process and a greater need for CAS to develop more concrete strategies to help prevent children from coming into contact with CAS. 


\section{Worker-Client Relationship}

Another important theme that emerged from the literature was that of the client-worker relationship. Palmer, Maiter, and Manji (2005) note that the parents valued emotional support, concrete help, and decent referrals to services from the workers. The mothers' also described a need for more on-going support, respite care, and appreciation from workers (Freymond \& Cameron, 2011). Parents explained that workers that were perceived in positive ways were those that were caring, genuine, those that provided exceptional help, workers who listened, and workers who were non-judgmental and accepting (Maiter, Palmer, \& Manji, 2006). Some workers felt that they needed to have a strong relationship with clients (Hoskins \& White, 2009). Workers that were perceived in negative ways were those that were judgmental, cold and uncaring, critical and insincere (Maiter, Palmer, \& Manji, 2006). Participants noted that workers and even judges may view a family's responses as refusing to comply with their demands (Miller, Cahn, \& Orellana, 2012).

Dumbrill (2005) notes that parents felt that workers either used their power over them as a way to control them, or that they used their power to work with them and support them. Further, the participants noted that workers could not relate to clients (Miller, Cahn, \& Orellana, 2012). Specifically, they thought that white workers could not relate to Black families. Participants also felt that workers were always changing their expectations, making it hard for them to keep or regain custody (Miller, Cahn, \& Orellana, 2012). Some parents and grandparents noted that they wondered if their efforts would ever meet the standards of child welfare (Miller, Cahn, \& Orellana, 2012). Hoskins and White (2009) further add to this conversation by talking about how frontline workers' decisions to apprehend can be connected to 
how they view themselves as a professional. Thus, Hoskins and White (2009) ask us to consider worker subjectivity and how that may be shaped by the agency.

According to Miller, Cahn, \& Orellana (2012) participants noted that lack of trust between the worker and the families significantly impacted the relationship between the worker and the client. While white families were more likely to view the welfare system as helpful, communities of colour were more likely to view such systems with distrust because of experiences in history where parental rights have been terminated (Miller, Cahn, \& Orellana, 2012). Participants said that there was a need to investigate where the client's mistrust was coming from (Miller, Cahn, \& Orellana, 2012). Participants noted that in many cases, there is a history and ancestry of being treated poorly by government officials (Miller, Cahn, \& Orellana, 2012).

Maiter, Palmer, and Manji (2006) add to this conversation by stating that a positive client-worker relationship may impact child welfare outcomes. Indeed Dumbrill (2005) notes that parents responded to child welfare intervention in three main ways: openly defying workers; "playing the game" by cooperating on the surface; or by working with them collaboratively. Parents who felt that power was being used over them usually fought or played the game, while parents who thought workers were using their power to align with them, worked cooperatively with them (Dumbrill, 2005). This is supported by Miller, Cahn, \& Orellana (2012) who note the need for workers to find commonalities between themselves and clients to build trust (Miller, Cahn, \& Orellana, 2012). They thought this might lead to improved outcomes for racialized families (Miller, Cahn, \& Orellana, 2012). 


\section{Gaps in Literature}

The literature reveals that the over-representation of Black children in-care in the child welfare system is a complex issue, fuelled by many different factors. Many pieces of literature (Clarke, 2011; Boyd, 2013; Anyon, 2011) acknowledge that the work environment at CAS may play a role in the over-representation of Black children in-care today. This environment can be characterized as largely neoliberal. Indeed Baines (2007) describes that neoliberal frameworks of management are focused on efficiency and effectiveness, usually resulting in standardization (as cited in Poole, 2010, p. 2). Further, Baines (2007) states that critical social work practices that do not contribute to such functions may be discouraged or punished (as cited in Poole, 2010, p.3). This is especially problematic given that various pieces of literature (Roberts, 2002; Ontario Association of Children's Aid Societies, 2016; Miller, Cahn, and Orellana, 2012; Boyd, 2013; Pon, 2009; and Gosine, and Pon, 2011) acknowledge that systemic racism is a significant contributing factor to the over-representation of Black children in-care at CAS. In a neoliberal environment focused on efficiency, and standardization, racism may not be focused on or properly addressed.

Yee, Hackbusch, and Wong (2013) argue that there is a need for an anti-oppression framework within CAS to combat oppressive practices. Conversely, Pon, Giwa, and Razack (2016) argue that we must be critical of anti-oppression. According to Pon, Giwa, and Razack (2016), anti-oppression emerged in the field of social work to address the hierarchies of oppression. Proponents of anti-oppression argued that it would allow oppression and discrimination to be considered through multiple, intersecting social locations, rather than through one primary lens such as race (Pon, Giwa, \& Razack, 2016). As such, anti-oppression 
may work in negative ways as well. Barnoff and Moffat (2007) note that anti-oppression may enable the issue of racism to be avoided (as cited in Pon, Giwa, \& Razack, 2016).

Instead, Pon, Giwa, and Razack (2016) call for the use of anti-racism instead because it looks at how racism exists as an intricate part of social life in order to counter denials that racism exists. Further, they acknowledge that anti-Black racism would specifically focus on the existence of a specific kind of racism geared towards Black peoples (Pon, Giwa, \& Razack, 2016). Indeed the Black African Caribbean Canadian Committee (2015) and the Government of Ontario (2017) found the need for training on anti-Black racism to combat structural oppression. The report One Vision, One Voice Part 2, acknowledges that an anti-Black racism lens should be implemented through the supervision of employees (Ontario Association of Children's Aid Societies, 2016).

Therefore, while the literature acknowledges that racism, specifically anti-Black racism, is a major contributing factor to the over-representation of Black children in-care, there is a gap present about how, or if conversations about anti-Black racism is occurring within CAS as a neoliberal agency. There is also a major gap about anti-Black racism in child welfare in Canada, resulting in the reliance on literature on anti-Black racism in child welfare in the USA. Thus, the literature leaves us asking how or if frontline workers carry out conversations about anti-Black racism specifically in a neo-liberal environment such as CAS in Ontario. As such, there is limited knowledge available about how such conversations may impact the work that frontline workers do, especially as it may relate to the over-representation of Black children in-care at CAS. 


\section{Chapter III: Theoretical Frameworks Defined}

There are three theories that will inform this paper: critical race theory, anti-Black racism, and critical race feminism. While critical race theory emerged from American legal studies, it has expanded into other disciplines, including the helping professions such as social work (Harris, 2012). This theory is concerned with investigating the paradox: how racism continues to exist despite almost universal condemnation in policies and "norms of polite society" (Harris, 2012, p. 3). Critical race theory considers racism to be normal in society today and integrated in social institutions, policies, and practices (Harris, 2012). Indeed Delgado (1995) notes that critical race theory acknowledges that racism is so engrained in society that it appears to be both natural and normal (as cited in Ladson-Billings, 2000, p. 264). As such, Harris (2012) argues that critical race theory is the study of hegemony, or how domination exists without force, or coercion.

As such critical race theory is also concerned with generally addressing racism and fostering social change. Critical race theory argues that white people have primarily benefited from civil rights legislation (Ladson-Billings, 2000). Therefore, a central tenet of critical race theory is that it recognizes that existing legal paradigms are limited in their ability to initiate social change, especially as legal precedents are often slowly argued to fight for the rights of racialized people (Ladson-Billings, 2000). Instead, critical race theory acknowledges that addressing racism requires widespread and comprehensive changes (Ladson-Billings, 2000).

According to Ladson-Billings (2000), critical race theory says that fighting for racial social justice begins with unveiling racism and making it apparent. To do so, critical race theory concerns itself with the epistemologies of racialized peoples, focusing on the experiences and perspectives of racialized peoples as it relates to understanding racism in society, policies, and 
institutions (Harris, 2012). As such, critical race theory places a great deal of significance on racialized persons telling their stories about racism as a way to disrupt normative assumptions that institutions, policies, legal scholarship and reasoning operate in objective ways (Harris, 2012). Critical race theory may utilize economics, sociology, history, and/or geography to offer more expansive theories about how racism exists structurally (as cited in Harris 2012, p. 12). Further, critical race theory has evolved to also focus on exploring and naming the white identity (as cited in Harris, 2012, p.14). It also includes a focus on white privilege, rather than discrimination, so that those who benefit from racial hierarchies are not left unexamined (Harris, 2012).

Critical race feminism is closely related to critical race theory (Childers-McKee \& Hytten, 2015). Similar to critical race theory, critical race feminism acknowledges that: racism exists in society; the narratives of racialized peoples are significant in disrupting normative ideas about society; race is a social construct; and the significance of action to resist and disrupt the status quo (Childers-McKee \& Hytten, 2015). Critical race feminism builds on critical race theory. Critical race feminism draws from critical race theory and feminism by "exploring social phenomena from the perspective of people doubly marginalized by both race and gender" (Childers-McKee \& Hytten, 2015, p. 395). Critical race feminism differs by centralizing the experiences, roles, and narratives of racialized women in the analysis of institutions, structures, and systems (as cited in Childers-McKee \& Hytten, 2015, p. 395). Thus, critical race feminism recognizes how gender and race intersect.

Razack, Smith, and Thobani (2010) explain that critical race feminism is also deeply linked to colonialism. Colonialism did not just operate through race, but also through gender (Razack, Smith, \& Thobani, 2010). As such, critical race feminism is about how "racialized, 
gendered relations...interlink with continuing coloniality" (Razack, Smith, \& Thobani, 2010, p.7). Specifically, Pon, Gosine, and Philips (2011) note that critical race feminism theorizes that colonialism and white supremacy continue to exist in settler societies like Canada. According to Razack, Smith, and Thobani (2010), critical race feminism does so by analyzing how "race and gender continue to re-inscribe the 'colour line' in an ostensibly race-gender - neutral liberal state" (as cited in Pon, Gosine, \& Philips, 2011, p. 400).

Razack, Smith, \& Thobani (2010) argue that racialized women are largely seen as nonintellectual and emotional. Indeed Pon, Phillips, Clarke, and Abdillahi (2017) note that Black mothers are constructed as "pathological and dangerous" in the child welfare system, through the exalted subjectivity of white workers. Exalted subjectivity is significant to upholding white supremacy as a tool that continues to perpetuate colonial attitudes, which continue to racialized and further perpetuate colonialism.

Finally, the last theory that will be used is anti-Black racism. According to Clarke, Pon, Benjamin and Bailey (2015), anti-Black racism, unlike critical race theory, is a dialectic. It speaks to both the oppression visited specifically on Black bodies and the resistance to that oppression. There are also multiple forms of anti-Black racism and multiple forms of resistance as made clear by Kumsa, Mfoafo-M'Carthy, Oba, \& Gaasim (2014). Because anti-Black racism is multilayered in meaning, anti-Black racism could also mean against the kind of racism perpetuated by Black peoples (Kumsa, Mfoafo-M'Carthy, Oba, \& Gaasim, 2014). This paper will be focusing on the first meaning of anti-Black racism as defined by Kumsa, MfoafoM'Carthy, Oba, \& Gaasim (2014).

Pon, Gordon, Phillips, Clarke, and Abdillahi (2017) note that anti-Black refers to a particularly malicious form of racism that is directed against Black peoples specifically. They 
note that this form of racism comes from the history of colonialism and slavery (Pon, Gordon, Phillips, Clarke, \& Abdillahi, 2017). It is this history that is the root of systemic and structural barriers that prevent all Black peoples from full and equitable participation in society. Indeed the Government of Ontario (2017) notes that discrimination against Black peoples exists in policies, services, and in decision-making.

Anti-Black racism exists on multiple, interrelated levels, including: "structural, systemic, cultural and individual levels" (Pon, Gordon, Phillips, Clarke, \& Abdillahi, 2017, p. 71). As such, anti-Black racism may operate through many different systems, including: housing, policing, immigration, child welfare, health care, employment etc. (Pon, Gordon, Phillips, Clarke, \& Abdillahi, 2017, p. 71). Indeed Lewis (1992) notes that;

While it is obviously true that every visible minority community experiences the indignities and wounds of systemic discrimination throughout Southern Ontario, it is the Black community, which is the focus. It is Blacks who are being shot, it is Black youth that is unemployed in excessive numbers, it is Black students who are being inappropriately streamed in schools, it is Black kids who are disproportionately dropping out, it is housing communities with large concentrations of Black residents where the sense of vulnerability and disadvantage is most acute, it is Black employees, professional and nonprofessional, on whom the doors of upward equity slam shut. Just as the soothing balm of 'multiculturalism' cannot mask racism, so racism cannot mask its primary target (as cited in Kumsa, Mfoafo-M'Carthy, Oba, \& Gaasim, 2014, p. 22).

Thus, this definition of anti-Black racism necessitates a focus on whiteness. According to Frankenberg (1993), whiteness refers to the structural racial privilege that white people have (as 
cited in Pon, Gordon, Phillips, Clarke, \& Abdillahi, 2017, p. 72). Thus, whiteness produces white norms, which simultaneously constructs the racial 'Other.' This is supported by Frankenberg (1993), who notes that it is from this privileged location that white people see other cultural practices (as cited in Pon, Gordon, Phillips, Clarke, \& Abdillahi, 2017, p. 72). Therefore, whiteness enables white people to be dominant in many ways, including in social, political, economic, cultural spheres of society (Pon, Gordon, Phillips, Clarke, \& Abdillahi, 2017). Whiteness is closely linked to Manicheanism. Manicheanism refers to the history of European culture and religion that associated whiteness with morality and innocence, and Blackness with criminality and immorality (Pon, Gordon, Phillips, Clarke, \& Abdillahi, 2017). This binary gets ascribed to bodies, so that Black peoples come to be seen as deviant and white people are viewed as just and innocent (Pon, Gordon, Phillips, Clarke, \& Abdillahi, 2017). As such Manicheanism fuels whiteness and, ultimately, anti-Black racism.

Finally anti-Black racism also means the fight against anti-Black racism as well (Kumsa, Mfoafo-M'Carthy, Oba, \& Gaasim, 2014). According to Clarke, Pon, Benjamin, \& Bailey (2015), anti-Black racism draws from Spivak's (1990) concept of strategic essentialism, so that Black peoples strategically unite under the shared identity of Black to fight against the specific kinds of oppression they face. Indeed Clarke, Pon, Benjamin, \& Bailey (2015) note that antiBlack racism is in line with communities fighting against oppression. Thus, the dialectic of antiBlack racism necessarily includes that of community organizing and resistance (Clarke, Pon, Benjamin, \& Bailey, 2015). This means that anti-Black racism is deeply connected to Black peoples' resistance against oppression.

Indeed Benjamin (2003) notes that anti-Black racism is deeply connected to Black radicalism, especially Black radicalism throughout history because it emphasizes how Black 
peoples have traditionally undertaken resistance across multiple, interrelated levels: locally, nationally and internationally. Various political ideologies connected to Black radicalism, such as anti-colonialism and anti-imperialism, have contributed to the Black community's efforts to mobilize against oppression (Benjamin, 2003). This also includes Garveyism/Afrocentrism, which stems from Marcus Garvey and focused on "not only retrieving a suppressed Black historiography, but heeding its narrative terms as well: the impending resurgence of a great panAfrican civilization" (Eburne, 2014, p. 4). Progressive parts of Garveyism/Afrocentrism and anti-colonialism worked to enable Black peoples to be aware of Black subjectivity as connected to Africa (Benjamin, 2003). According to Weedon (1987), subjectivity means the thoughts, both unconscious and conscious, about one's sense of self and their relation to the world (as cited in Benjamin, 2003, p. 65).

According to Benjamin (2003), resistance has been intrinsically connected to Black subjectivity, as it has developed through political, social, and underground movements (Benjamin, 2003). "For African Diasporans in Toronto and elsewhere, having Black and African consciousness meant rejecting the historic demonization of Africa and developing a positive selfidentity and subjectivity as a descendent of Africa" (Benjamin, 2003, p. 66). Thus, progressive elements of political ideologies present in Black radicalism were central to problematizing negative views of Africa and Blackness and shifting away from such views (Benjamin, 2003). This is deeply connected to the rise of a critical consciousness, as it counters hegemonic ideology about Black peoples and enabled Black peoples to view themselves in different ways (Benjamin, 2003). As such, Benjamin (2003) notes that opposing political, social, and economic oppression is a critical component of anti-Black racism today. According to Clarke, Pon, Benjamin, and Bailey (2015), anti-essentialist principles must be applied when organizing from an anti-Black 
racism framework. This "means that there is no way of phenotypically or culturally being identified as Black. Black is intersected...with different social identities” (Clarke, Pon, Benjamin, \& Bailey, 2015, p.155). Thus, anti-Black racism must consider diversity in overlapping social locations of community organizers.

Finally, as resistance and organizing is a deep part of anti-Black racism there is a focus on leadership (Benjamin 2003; Clarke, Pon, Benjamin, \& Bailey, 2015). Furthermore, antiBlack racism utilizes “indigenous knowledge of Black leadership” (Benjamin, 2003, p. 69). Such knowledge has fostered positive changes that have greatly impacted Black lives (Benjamin, 2003). Indeed, it is Black leaders who have produced conditions that enabled individual agency, as well as community resistance (Benjamin, 2003). "The theory or theoretical framework of antiBlack racism can therefore promulgate the lessons gained from these traditions that have been so nurturing of agency and resistance in opposing hegemonic discourses and ideologies" (Benjamin, 2003, p. 70). Benjamin (2002) notes that this begins with an understanding that Black leaders through history who have worked to achieve systemic changes have often been undermined and minimized by people who hold power and such leaders have been attacked by the state (as cited in Clarke, Pon, Benjamin, \& Bailey, 2015, p.155). As such, anti-Black racism acknowledges that leaders must be skilled strategists (Clarke, Pon, Benjamin, \& Bailey, 2015).

Critical race theory, critical face feminism and anti-Black racism will be central to this paper in multiple ways. As critical race theory asks us to consider how racism continues to exist despite condemnation, it necessitates that I interrogate how racism persists at CAS despite their focus on anti-oppression. Further, as Black children are over-represented in the child welfare system, anti-Black racism will primarily be used to better understand how this specific and particularly malicious form of racism exists systemically at CAS. Critical race feminism 
requires that, specifically, I consider how conversations about anti-Black racism must include gender. Indeed Benjamin (2003) notes that an important part of anti-Black racism is understanding that Black women face multiple, intersecting forms of oppression.

Additionally, because critical race theory calls for an exploration of white identity, it necessitates that I theorize around how whiteness permeates CAS and exist systemically at the agency. Critical race feminism's focus on colonialism will provide an analysis will contribute to this by asking me to consider how Manicheanism has worked to construct the white child welfare workers as exalted nationals who are benevolent and caring and how this may influence conversations about anti-Black racism and their significance. McKenzie-Mohr and Lafrance (2017) note that we must ask how master narratives render certain things invisible. When that becomes visible, we may see the ways in which Black mothers are still marginalized. Additionally, the focus on whiteness also requires that I consider how even racialized workers may benefit from systems of whiteness, or contribute to it.

Critical race theory will ask that I consider barriers preventing conversations about race at the agency. Because of critical race theory's focus on achieving change, it suggests that I ask how conversations about racism can be promoted within CAS and how this may begin to contribute to addressing the over-representation of Black children in-care. Critical race theory, therefore, supports my methodology and method, placing importance on the voices of racialized workers, but also white workers as well, as it necessitates that I also look at the white identity to begin marking it. 


\section{Chapter IV: Methodology and Method}

This research was qualitative. Qualitative research can be described as "research which sets out to provide an impression...to tell what it is like to be, do, or think something" (Bouma, Ling, and Wilkinson, 2012, p. 46). In this case, I sought to better understand what it was like for critical frontline workers to carry out conversations about anti-Black racism. As such, this was a narrative study, specifically an oral history. According to Creswell and Poth (2017), an oral history is when personal reflections about events, their causes and effects are gathered from one or many individuals. The context of these personal reflections, as a kind of narrative study, can include stories told about organizations (Creswell \& Poth, 2017). In this case, I sought the reflections from self-identified critical frontline workers, at the organization Children's Aid, about conversations around anti-Black racism, the impacts of these conversations, how they are carried out and brought up, and barriers to such conversations. I hoped that their voices around this topic would highlight how anti-Black racism and whiteness continue to exist at CAS. Further, it is noted that an oral history can be guided by an interpretative framework (Creswell \& Poth, 2017). In this case, the interpretative framework is anti-oppression.

As childhood is socially constructed, it is important to note that the term 'children' is pervasively used in this study to refer to those 18 years of age and under. This is how children are defined under the Child, Youth and Family Services Act (2017). The Child, Youth and Family Services Act (2017) aims to promote the well-being of children and defines many of the roles and responsibilities of professionals working with children, including child welfare workers. Throughout this study and in the research questions posed, the term 'youth' may be used interchangeably, also referring to those 18 years of age and under. 
The inclusion criteria for this study included that: participants had to self-identify as a critical frontline worker, or as one familiar with anti-oppressive practice, anti-Black racism, critical race theory or other critical approaches to critical social work. They also had to be currently employed at CAS or had been employed there within the last two years. To recruit, I used informational posters. The sampling method used was snowballing. According to Bouma, Ling, and Wilkinson (2017) this sampling method was used when researchers need to gain access to specific kinds of people, but know only a few who may meet the criteria (Bouma, Ling, and Wilkinson, 2017). In this case, researchers approach those who are available and ask them to reach out to others who they may know, who may, in turn, continue to reach out to others who they know as well (Bouma, Ling, and Wilkinson, 2017). In this way, the sample size of eligible potential research participants grows (Bouma, Ling, and Wilkinson, 2017). In this case, I sought self-identified critical frontline child welfare workers. I knew few frontline workers and sent recruitment flyers to peers who I had completed my undergraduate degree with. I also emailed flyers to members of the MSW program at Ryerson, as some were completing their student placements at CAS, or had previous connections to CAS or Family and Children Services. They then passed on information about my research to their contacts and further asked them to continue to pass the information on. I also emailed copies of my recruitment posters to professors, mainly those with backgrounds in child welfare, to distribute.

Additionally, I created a private Facebook study account, to recruit through a Facebook post. Members of MSW program at Ryerson were invited to join, as well as social work colleagues were invited to join. They could request a poster to be emailed to them to directly pass on to potential participants, or they shared the post to alumni pages for Schools of Social 
Work at other universities. All interested participants contacted me directly at my Ryerson email address.

While this sampling method helped to grow my sample size, it, along with the recruitment tools, also posed difficulties. Nothing in the recruitment tools encouraged the participation of workers who felt that conversations about anti-Black racism did not happen at their agencies. The recruitment tools did not highlight how structural and systemic issues at the agency would also be discussed. Because I was not directly involved in recruiting participants, I could not verbally explain that either. Thus, the recruitment tools and the sampling methods did not properly account for how white guilt and white fragility may hinder the recruitment process and ultimately deter research participants. Indeed general comments from initial recruiters suggested that many of their contacts were uncomfortable participating or felt that racialized workers should be the focus of the study. Specifically, one initial recruiter noted that their contact felt that conversations about anti-Black racism did not happen and would have very little information to offer. Another initial recruiter said that their contact said that there was a team of racialized workers at her agency and that they would have more to say on the topic of anti-Black racism. Furthermore, another recruiter informed me that CAS is conducting its own research on anti-Black racism and was discouraging workers from speaking to external researchers.

Altogether, I interviewed 3 participants. While, I felt that it was important to understand how participants specifically identified in terms of both race and gender, I did not include such specific questions in my demographic questions. This is because the Research Ethics Board had concerns about protecting the identities of research participants and it may have been challenging to gain approval if such questions were asked as they may have made it easier to identify participants. To address these concerns while also trying to understand the social locations of 
research participants, I only asked if they self-identified as racialized. Participant 2 identified as racialized, while Participant 1 and Participant 3 did not. Participant 1 was the only participant who identified as new at the agency. All participants qualified for the study, as they selfidentified as critical frontline workers, either currently employed at CAS or employed there within the last 2 years.

The interviews conducted were semi-structured, lasting anywhere from forty minutes to just over one hour. They occurred over Skype, or in a study-room in a public library, as it would not be ethical to conduct such research at their place of work, given the nature of the subject. Open-ended questions were used to encourage conversation with the worker. In conducting the interviews, I tried to be aware of how narratives act as a form of resistance (McKenzie-Mohr \& Lafrance, 2017). Even though the CAS workers are in a position of power, they may still be restricted in how they work and how they can have conversations around race at their agency. In these ways, they may be oppressed in how they can work. Through my research I hoped to give workers a space to resist such policies and practices and talk openly about what is wrong about how conversations around anti-Black racism happen at CAS.

To do so, I tried to be aware of the power dynamic that existed during the interview. Particularly, as a student part of a critical MSW program and as a racialized person, I realized that participants may feel judged if there was a lack of conversation about anti-Black racism, especially given that the recruitment tools and sampling methods did not mention that structural issues would be talked about. Indeed Ladson-Billings (2000) notes that oppressed people safeguard themselves by withholding and altering data. Deliovsky (2017) supports this by saying that participants may engage in impression management to control how the researcher sees them. 
To mitigate such a power imbalance and promote the comfort of research participants, I tried to ensure that I gave participants the space to speak, so that they could fully speak about their experiences as frontline workers. I hoped this would enable them to also speak about some of the good work that they do with clients. Further, I also tried to ensure that that there were questions that focused on the structural issues at CAS and how that may impact a critical frontline worker. In this way, I tried to ensure that questions did not focus on individual failings of frontline workers, but tried to bring the interview include some focus on larger structural issues at the agency. While I believe these things mitigated the power imbalance present in the interview process, I think it would have been better if I had acknowledged from the start of each interview that the goal of this research is not to assign individual blame/responsibility for the over-representation of Black youth. Further to protect participants and ensure they felt comfortable speaking, the names of participants have been removed and replaced by pseudonyms and the specific agency they work for has not been identified.

Participants were each emailed a copy of the consent form to view, but it was also explained prior to the start of every interview. Participants were told the purpose of the research, potential risks, and it was made clear that they have the right to withdraw from the study, or withdraw their information at any point up to the MRP being completed. They were also told that they do not have to answer every question during the interview and that they could choose to stop the interview if desired. Participants were also informed both verbally and through the consent form that they would be audio-recorded on a password-protected device. I told them that these recordings would be transcribed and stored on an encrypted USB. For interviews conducted in-person, consent forms were signed prior to the start of the interview. For interviews conducted via Skype, I requested that the consent forms be signed, scanned and emailed back as 
soon as possible; however all participants verbally consented to the research prior to interviews taking place. All participants received a $\$ 10$ Starbucks gift card in appreciation of their time. Once the audio-recordings were transcribed, they were analyzed for themes. Potential themes were identified through the theoretical frameworks that inform this research paper: critical race theory, critical race feminism, and anti-Black racism. Transcripts were read line by line and each theme was assigned a colour. Four major themes emerged from the interviews. 


\section{Chapter V: Findings}

Critical race theory asked me to consider how racism exists at CAS despite the existence of policies and strategies aimed at eliminating it. More specifically, anti-Black racism asked me to consider how particularly malicious forms of oppression directed against Black peoples still exist at CAS. Four interrelated themes emerged that provided a great deal of insight into this once analyzed.

\section{Theme 1: Lack of Conversation about Anti-Black Racism}

When talking about conversations about anti-Black racism, all participants spoke about their direct supervisors. All of them felt that they had supervisors who possessed a critical lens. As such, they felt they were able to have conversations about anti-Black racism with their direct supervisors if they needed to. While conversations could happen directly with supervisors who possessed a critical lens, all participants acknowledged that not everyone has critical supervisors. Furthermore, participants acknowledged that these conversations about anti-Black racism may not be prevalent with co-workers. When asked if he felt like he could have conversations about anti-Black racism with other co-workers, Participant 2 responded by saying:

Uh, like, again, it varies right, so I think just...like at CAS, you start learning whose your allies, whose- who are the ones who come with that lens, right, so that you're able to have those, ah, conversations with them, and work with them because, again, there's you know many workers there that come with an anti, anti-oppressive background and stuff like that, but you know, some people may not believe in it, they may not exercise critical reflection or critical thought as much as others, or as much as you think, um, you should, so it's very, um- it like depends, right. 
When asked if she had or if she had seen any of her colleagues start conversations about antiBlack racism, Participant 3 stated:

Um...no, my instinct is to say no and I worked - like my teams, the different teams I was on, umm... were diverse not with respect to male, female because there's more men than women, um, but in terms of age, working with, uh, like bl, Black workers, or racialized folks...

Furthermore, Participants 1 and 2 noted that conversations about anti-Black racism do not really happen on a bigger scale, beyond individual conversations. Participant 1 stated:

Ahh, I didn't really...I cannot remember any big conversations about it. We sometimes talk about it a little bit at team meetings, but it's not really like agency wide conversation... We try not really- I don't know... we don't really discuss. Because the family- we're trying like...Like...like I wouldn't say we talk about it much.

When asked about how it's discussed in team meetings, she went on to say that 'it's briefly. It's not really... like- and I don't even know why. Maybe they expect everyone who comes, already knows it and uses it. I don't know, but it's not really discussed."

Participant 2 stated:

when it comes to, um, the bigger Society and having meetings and things like that, um, there's not a safe, there's not a safe space to really discuss that, right, because once you really get into that discussion, you're really questioning the work that CAS does...now comes off as are you a rogue worker? are you not going to follow through on things? Are you now a problem, right? 


\section{Theme 2: Participants doing their best to assist families}

Speaking with participants was quite insightful. While participants spoke of having some colleagues who may not work in critical ways, or work differently than they do, it became clear that interview participants themselves did their best to work from a critical lens to help the families they worked with. For example, Participant 1 and Participant 2 recognized that some families should not be in contact with CAS at all. As such, they worked to close those files quickly and worked to prevent those cases from being opened again. Participant 1 did so by recognizing that some calls may be "malicious" or "something minor" and, as such, stated that: "the way you write the report, um, that can help them if we get, if we get another concern like that. So if someone, if someone reads this report, they might not open the case again." She felt that this helped families avoid unnecessary stress.

Similarly, Participant 2 talked about how he enjoyed his role at the agency because he could be the "first point of contact" for families. He acknowledged that there are some families who shouldn't be in contact with CAS, but are 'because it's about who's being watched, and who's accessing services in the community." According to Participant 2 this tends to be impoverished families, which "correlates with people of colour." Being the first point of contact for these families allows him to go out and meet families and shut it [the case] down and not let them continue into the system, versus, um, unfortunately if it could be a person who doesn't come from a critical space or say, unfortunately, say maybe a white worker who may not understand like the nuances of certain cultures.

Participant 3 said that she "always worked with the, from the frame of mind that by doing as much as I could for the family, maybe they wouldn't be back in our involvement." She further 
talked about recognizing systemic oppression that clients may face. For example, she recognized that "the majority of cases are not horrific injury or sexual abuse. The majority of people are struggling because life is hard and there are a lot of barriers." Additionally, she recognized that families in contact with CAS face oppression because they "don't know any part of the system." As such, she "spent a lot of time explaining the system" and letting them know their rights.

When she needed them to sign something she would let them know "[that] this is what it means, but you don't have to, but this is how it's perceived if you don't sign it and this is what it means and do have a file but this is what's in it."

This was similar to Participant 1 who talked about trying to be transparent with families and "explaining every single step, " letting families know "this is the first step, this is the second step, then I'm going to consult, then we're going to talk about collaterals, if you don't sign that's fine." By doing so, she felt she was making the process easier for families, which was important because not every experience with CAS is pleasant for families. For Participant 1 and 3 building rapport with clients was important. Each spoke of successfully working with families that other colleagues may have had trouble working with. Participant 1 noted that a significant part of being able to do so was beginning from a place of not knowing.

Thus, while CAS has frontline workers who may not be critical, they also have frontline workers who are and who are doing their best to help the families they work with. Indeed, all participants noted that they chose to participate in the study because they felt that the topic was important or wanted to see change around this issue. This means that the lack of conversation around anti-Black racism at CAS is not because all individual frontline workers do not want to have such conversations or see them as insignificant to the work that they do. 


\section{Theme 3: Barriers}

Thus, it is important to look at the systemic and structural barriers that may exist at CAS that prevent prevalent conversations about anti-Black racism. Participants revealed that multiple barriers exist. One major barrier that became apparent after conducting interviews was that considerations about anti-Black racism were not built into the work that frontline workers do. For example, Participant 2 said that

The other issue, kinda going back to, um, say like anti-Blackness or just doing critical work, um, the issue I always see is that when it comes to, like say, the agency and talking about AOP and things like that it's just really about encouraging workers to, um...encouraging workers to self-reflect, um, and be mindful of their biases, but there's no - really in the foundation of the work, there's no safeguard for it, right. That's where the problem comes, but there's nothing in, you know, your safety assessment, or the write up, or your investigation, or your plan of service to really outline about to, you know, the outline, and maybe, like, what is maybe like the background of this worker, how does the thoughts, how does the thoughts and biases, um, impact, even just a little thing about how does race, race and culture, or, you know, gender and sexuality, how does that impact the case- but, there's nothing like that in the actual work or documents... So I think that's, uh, you know, a problem because then it goes down to worker by worker, cause, again, you can plug in another worker into a case and that work will look totally different and it really shouldn't be, right... 
Thus, his comments reveal that there is nothing in the actual documents, such as the safety assessment, that would encourage workers to critically reflect on their own biases and how they may be perpetuating anti-Black racism.

Participant 3 talked about the kind of language embedded in the work that they do on the frontline and how this may contribute to the lack of conversations about anti-Black racism. Participant 3 also talked about how the language of diversity was often used at the agency and how this may have hindered conversations about anti-Black racism. She described that in Canada, we always want to be polite and there's such a push to be inclusive, diverse, multicultural that no one wants to talk about that [anti-Black racism]. I think that's what it is...but I feel like um...you'd have workshops on, ah- but it was more about being about, you know, broader. It was more about the things you could do to be better and all encompassing or embracing differences. Again, that's not the hard stuff, right.

She noted that "polite language" is used at CAS, saying that "they word things politely like, you know, disadvantaged, at risk, or- and all that's true- um, but the hard conversations about who the actual people are that we service, um, is not discussed...Um, and...I just, I think it's a bit like white fragility." Indeed Participant 1 said that she had seen cultural matching at her agency, while Participant 2 stated that cultural matching was a prevalent strategy in his department. Thus, when asked if it would make a difference if managers began shifting away from diversity and using words like 'white fragility,' Participant 3 said

Well, yeah I do think, I also think never mind just shifting away, I also think moving away- not moving away, you're gonna have- there's a whole CAS speak, right, short forms, I'm sure if anyone was sitting there, they'd just be like 'what?' 
when you're doing things, so never mind removing anything, just adding in non

CAS speak to make people pause

Participant 3 talked about language in other ways as well. Specifically, she talked about the language of liability and investigation at CAS. She said:

...the natural reaction is they [workers] wait for the training to come down, because everything is about liability, it all goes back to the Child and Family Services Act and court and not just like getting in trouble, but like big deals, like babies dying or safety issues or subpoenas or immigration...

When speaking about all the boxes workers have to check off through mandatory paperwork, she noted:

when you come back to the office and you're accountable, like they're flagged, they pop up, they alert, they do all this stuff which over the last several years it's almost like surveillance, it became more and more like that, that the focus became more about that stuff.

Thus, there is a strong focus on liability, making the process of child welfare investigations significant for frontline workers. Remarks from Participant 2 reflected this, as he noted that there are things that they are mandated to do by the Ministry. Participant 3 said that "within the Society, Children's Aid as a whole including management, every move you make is like, um, every step is legislated and so, unless -so they don't create that room for that space [for conversations about anti-Black racism]." She noted that "people could really hide behind all the wording and the process of investigation. Conversations were focused mainly on the professional role of workers, with limited acknowledgment of the social identity of the worker. Participant 3 said that 
the conversation wasn't that I'm a white worker, it was I'm a CAS worker...it wasn't talked about about what race, so again it's easier, we're all CAS workers, cause then it also sorta minimizes the experiences of racialized workers in doing that, it would keep, say, myself ignorant to that situation.

Therefore, there are multiple ways in which Ministry tools may hinder conversation about anti-Black racism. Unfortunately, there are other ways in which the Ministry may act as a barrier to anti-Black racism. Participants 3 and 2 spoke of funding received from the Ministry. Participant 3 said " it seems like people that have the power, that, that give the funding, or make the decisions that folks that we service are not equal, so- because if they felt that they were equal then why are we struggling for money to service them?" Participant 2 said you get funded based off the cases open and what you do with them, right. You get more funding if investigate a case and it goes to, say, ongoing services than if you just investigate a case and you close it; or if you investigate and send them services. So a lot of workers, supervisors will be, even if the family doesn't want services, then they'll say at least label it as a community link and send them services so it looks like we provided something, so it can add to the funding He further stated, the less children you bring into care, the less group homes you need to open, less group homes you have to pay for, less CYWs you have to pay to man these foster homes, so there's also a financial benefit to, um, for the Societies to reduce the amount of care, to reduce the amount of children in care, right, but the thing is, is that on the other sense now is um, again, I said it before, we receive funding for cases that open right, cases that we open and we investigate 
right, so as much as, again, cause like we know and screeners know, and like supervisors and senior service managers they know that like we get a lot of cases that on the paper you know is bullshit, or we get a lot of, um, malicious calls, right and like you know from the referral but the thing is, its not in the best interest of the society to not to take them, right. It's not in the best interest of the society to tell schools, our number one referral source to, to reduce the referrals because again we receive funding per cases that we get and open up right, so that's kinda where the issue lies of that there's an actual financial benefit to opening these files, right...

Participants 2 further talked about the consequences of such a funding structure as it relates to limited conversations about anti-Black racism. He said that: ....pen conversations about how to reduce our kids in care, that's a very open conversation that you can have, but, again, that's to the benefit of the Society, but a conversation of - it, it shouldn't be a conversation of reducing our child- our Black kids in care, it should be a conversation of reducing our involvement with Black families period, but that impacts our bottom line, so that's the issue.

This was supported by Participant 3 who stated that conversations about reducing overall numbers of children was the open conversation at the agency. Specifically, she said ...to me, it's like they forget you're physically in touch with people who have emotions and you're being respectful and trying to help- support these people, so I feel like these conversations about bringing youth in care, again, it was really safe about reducing the overall number or teenagers don't do well in care, but there were not discussions about why out of the 32 teens, you know, why are 27 of 
them Black and, and should we be looking at what's going on that we- how did we come to apprehend 27 Black youth...

Participant 2 said that these conversations are so open at the agency because it looks good for an agency that is already perceived as 'baby-snatchers' by community members.

It is important to consider how conversations about anti-Black racism can be built into the work that frontline workers do, especially as all three participants described that the work in their departments and/or roles was quite fast-paced. Participant 1 also spoke about paperwork, saying that she feels like she has more paperwork than she meets with families. Participant 3 supported this, saying that there's a lot of timely paperwork that needs to be done. Further, Participant 1 said that her day could be unpredictable and it could be difficult to plan or schedule her day. Further to that, Participant 3 noted that there will days that she's on the road, in the office, or on the board on call. Thus, it may be difficult for workers to carve out specific time dedicated to conversations about anti-Black racism. As such, considerations about anti-Black racism should also be engrained in steps that frontline workers take as they work with families.

\section{Theme 4: The role of Upper/Senior Managers}

Another barrier to conversations about anti-Black racism is upper, or senior levels of management. Participant 2 talked about the need for safe spaces for such conversations to occur because once you really get into that discussion about anti-Black racism "you're really questioning the work that CAS does... it now comes off as are you a rogue worker? Are you not going to follow through on things? Are you now a problem?" His statement reveals that workers do not feel safe in having these conversations openly, as they fear how they may be perceived as an employee at CAS. Indeed, Participant 2 spoke of a co-worker who pressed the issue of antiBlack racism and was not well received. As such, Participant 2 noted that upper management 
must play a central role in helping creating safe spaces for conversations about anti-Black racism. Particularly,

I think it, I mean, I think like if the people on top, so, you know, whoever's like the $\mathrm{CEO}$, the senior services managers, are the ones coming out and saying that you know, we want, we want to hear this, maybe they/re the ones who even come out and recognize that these are the certain issues that- of child welfare, and able to come out with that, then it would be like, ok, at least we know the ones on top are on board, or understand and that we can now feel more comfortable having those conversations, um, you know, in the public sphere of the company, but when that's not the case then, again, the fear is that, um, if you are coming out, then what's the impact, what could be the repercussions of that right, because at the end of the day like, again, people need to put food on their table too, right. Um, so, can it- can those conversations impact, like, your livelihood, or how you're perceived, um, in the agency, so I'm not sure, I mean, that's, that - it was a good question.

Participants 1 and 3 also felt that upper management needed to do more to enable conversations about anti-Black racism. Participant 3 said:

Um it's a lot if power that you put in the workers hands and yet- so it's like we hold a lot of power, but when you think about when we're talking about things like this, we have such little room to make impact, so I just feel like it has to start like the top-down Similarly, when asked how CAS could help workers have conversations about anti-Black racism, Participant 1 said: 
uh, again, if they, ah, basically, they need to start this conversation, not the frontline worker. They need to start it. This is how they can help because otherwise, we cannot, basically we don't even have time and space to start any conversation... 


\section{Chapter VI: Analysis}

\section{'White Safety and Harm' and 'White Liability' Embedded in Child Welfare}

The statements made by participants are significant in many ways. When participants talked about considerations about anti-Black racism not being built into the work at CAS, tools, like risk assessment, were mentioned. Risk assessment tools are used to enforce the Child, Youth and Family Services Act (2017) which mandates reporting the abuse of children, including the physical harm, sexual abuse, emotional distress caused by the actions or inactions of a parent or caregiver.

Risk assessments measure the future risk of abuse and are conducted "in accordance with the assessment tool in the Ontario Child Protection Tools Manual" (Ministry of Children and Youth Services, 2016). In the manual, the family risk assessment talks about housing, giving the worker the option of scoring up to 2 points against the family if they live in a home with health or safety hazards such as "exposed wiring, inoperable heat or plumbing, roach/rat infestations" (Ministry of Children and Youth Services, 2016). Further, this tool also talks about child abuse and neglect, noting that a worker may score up to 1 point against the family if the child sustained an injury ranging from "bruises, cuts, and welts to an injury that requires medical treatment or hospitalization" (Ministry of Children and Youth Services, 2016). As such, standards to measure risk are built into these tools. This was noted by Participant 1 who said

With risk assessment ... if the family, lets say have previous case experience, but otherwise the family is fine, the family might be high risk.

So even if you have a child under two years of age, your risk level goes up. So, it doesn't really matter what you do. 
As such, there is a heavy emphasis on physical harm and neglect that children may endure in their families.

When participants spoke of risk assessment tools used by frontline workers they noted that there was nothing built into those tools to make workers reflect on their own social location or biases. Nothing in the risk assessment tools encouraged workers to reflect on anti-Black racism and how this may cause a child harm if they are removed unnecessarily from their home, or how families may be negatively emotionally impacted by being in contact with CAS. This is supported by Participant 1 who described that one of the reasons that conversations about antiBlack racism are not more pervasive is because

it's fine until it's fine, like until it's not, so something happens then we start having conversations about it, right? So until it's everything's fine, so everyone is doing everything as usual, but if it's something unusual, I would say, then they would start doing something about it.

Her comments suggest that while the current over-representation of Black children is acknowledged by CAS, the full impact of how this impacts Black families and communities may not be fully recognized by CAS. As Participant 1 notes that it may still be perceived as "fine" and as "usual," even though it is not.

To be clear, there is no doubt that physical, sexual and emotional abuse constitute harm to a child; however, it must also be recognized that anti-Black racism is a form of harm and may be perpetuated by welfare workers against Black children through recognized and unrecognized bias. As Phillips and Pon (2018) note there is a great deal of literature that highlight the experiences of Black families in contact with CAS. According to Phillips and Pon (2018) Black families who took part in OACAS consultations shared their experiences with CAS, revealing 
that Black children and parents may not be shown compassion by CAS workers. According to Clarke (2011) children removed from their homes were impacted in multiple negative ways. Children reported feeling anger and frustration as they felt like they were being surveyed and constantly watched by foster families; a loss belonging, especially as they may have been separated from siblings; low self esteem; and disconnected from family, culture, and community (Clarke, 2011). It can be argued that these are all forms of harm being experienced by Black children. Thus, the risk assessment tools reflect a standardization of one particular kind of harm that is perpetuated by families. In doing so it maintains one kind of safety that does not consider the impacts of racism, or that child welfare workers may perpetuate this kind of harm. Arguably, this definition of safety is deeply engrained in a history of colonialism and the history of CAS, as this is related to exalted subjectivity.

According to Thobani (2007) there is a link between colonialism, slavery, immigration, the welfare state and child welfare (as cited in Pon, Gosine, \& Phillips, 2011). According to Coulthard:

a colonial relationship can be defined as one characterized by domination; that is, it is a relationship where power-in this case, interrelated discursive and nondiscursive facets of economic, gendered, racial, and state power-has been structured into a relatively secure or sedimented set of hierarchical social relations that continue to facilitate the dispossession of Indigenous peoples of their land and self-determining authority. Colonialism was a central feature of the modern period beginning in the 1400s. During modernity, the concept of race was drawn upon to legitimize the exploitation, domination, and annihilation of non-Western people, 
while simultaneously constructing the white race as superior to all others (as cited in Phillips \& Pon, 2018, p. 84-85).

Thus, colonialism was more than the theft of land, but the spread of a worldview that privileged white people and, thus, the spread of whiteness as a system of structured privilege. Deliovsky and Kitossa (2013) note that during the era of modernity, Africa was constructed as the "Dark Continent," filled with "demonic and dangerous savages" in the imaginations of Europeans (as cited in Phillips \& Pon, 2018, p. 90).

According to Thobani (2007) immigration policies kept non-preferred races out of the country (as cited in Pon, Gosine, \& Phillips, 2011). The non-preferred races were non-white, especially Black women, as they were seen as 'morally degenerate' (as cited in Pon, Gosine, \& Phillips, 2011). Thobani (2007) asserts that white people held status as exalted nationals through citizenship (as cited in Pon, Gosine, \& Phillips 2011). As the welfare state expanded, the nation state was perceived as helpful to all members of society even though racialized immigrant families could not receive benefits of the welfare state (as cited in Pon, Gosine, \& Phillips, 2011). As such exalted nationals were still seen as kindhearted, caring, and compassionate (as cited in Pon, Gosine, \& Phillips, 2011).

In the 1960's when the child welfare system came to represent the welfare state, it was social workers, particularly white female social workers who reflected the ideals of kindness and caring, thus purporting Manicheanism (as cited in Pon, Gosine \& Phillips, 2011). In this way colonialism was achieved through gender. This is supported by Razack (2005) who notes that "white women as the savior of less fortunate women is a centuries old colonial formula" (as cited in Phillips \& Pon, 2018, p.86). Thus, child welfare institutions have played a major role in 
maintaining the exalted subjectivity of white workers. Today, it is important to note that racialized workers too may try to benefit from the status of exalted national.

As such there has been limited interrogation about the definition of harm represented in the Child, Youth and Family Services Act (2017), as enforced through risk assessment tools. The definition of harm and, thus, risk assessment tools are rooted in constructions of exalted national subject. The only definition of harm offered is forms of maltreatment against the child by the parent because child welfare workers are largely constructed as good, and benevolent through a colonial history of Manicheanism and slavery. The harm that a worker may impose on a family by perpetuating anti-Black racism is not a consideration built into the definition of harm purported by the Ministry of Children and Youth Services, or in risk assessment tools at CAS.

Further, risk assessments simultaneously act as a form of bio-power (Phillips \& Pon, 2018) carrying out Manicheanism and reinforcing constructions of the exalted subject. Phillips and Pon (2018) note that today, Manicheanism exists on Black bodies as fear because fear has always been a significant part of racism. Fear of Black bodies may result in seeing Black mothers as dangerous to their children. Where bio-power refers to "operations of power on individual bodies in order to optimize its capabilities, efficiency, usefulness, and docility," risk assessments may be seen to work to correct the behaviour of Black mothers according to white middle class standards (Phillips \& Pon, 2018, p. 85). This is supported by Phillips \& Pon (2018) who noted that an example of bio-power may include the assessment of the risk to a child. Thus, risk assessment tools uphold constructions of the racialized other as 'morally degenerate,' simultaneously reinforcing the construction of the child welfare workers as the exalted subject. Thus, the definition of harm offered in the Child, Youth and Family Services Act (2017) reflects a position of structural advantage held by white welfare workers, and racialized workers who may 
also uphold and benefit from systemic white privilege. Risk assessment tools enforce this structural advantage.

The definition of harm seems to be deeply connected to a specific kind of liability and professionalism at CAS. As Participant 3 noted, there is a deep focus on liability at CAS. When workers are in the office, and not directly working with families in the community, check boxes and reports flag, pop and alert to prevent "big deals like babies dying." Participant 3's comments reveal that the flags and pop ups hold some authority, as they act as a form of surveillance on workers ensuring that they are acting as responsible investigators to prevent death and harm of a child. Thus, this surveillance system legitimizes and defines liability in one specific way. Liability is not discussed in the context of being responsible for how anti-Black racism may impact the work frontline staff do with families. Indeed Participant 3 noted that CAS is disruptive in the lives of families, especially as they will have files for a long time. This further reinforces constructions of workers as benevolent exalted subjects belonging to the Canadian nation.

Current definitions of legitimate harm, liability, and professionalism further perpetuate anti-Black racism through child welfare work because the harm and suffering of Black families in contact with CAS is not prioritized at the agency. Anti-Blackness legitimates "a high tolerance for brutality and indifference toward African-descended people's suffering" (Phillips \& Pon, 2018, p. 90). By not including the negative impacts that Black families endure in the Child, Youth and Family Services Act (2017), we fail to have this engrained in the work done daily at CAS, through risk assessments and the definition of liability at the agency. As such, the agency and the Ministry of Children and Youth services continue to be largely indifferent to the 
suffering of Black families, thus continuing to suggest a high tolerance for brutality by this population. As such, anti-Blackness is perpetuated.

\section{$\underline{\text { Perpetuating Anti-Black Racism and Preventing Conversations }}$}

In taking a critical race feminist approach, other comments made by participants reveal how CAS' funding structure is both perpetuating anti-Black racism and preventing conversations about anti-Black racism from occurring in more pervasive ways. While CAS receives funding for closed cases, participants talked about how funding is limited and is also linked to cases that are opened, investigated and sent to ongoing services. Participant 2 said that there is therefore a "benefit to opening these cases." Because Black families are surveyed and policed by community members, this perpetuates anti-Black racism in many ways. For example, Davis (1983) notes that “during slavery, Black women were not considered 'mothers at all...they were breedersanimals, whose monetary value could be precisely calculated in terms of their ability to multiply their numbers (as cited in Clarke, Minster, \& Gudge, 2018, p.190). Davis (1983) says that "as breeders, they had no legal claim over their children who could be sold to other slave owners 'like calves from cows' (as cited in Clarke, Minster, \& Gudge, 2018, p. 190). Thus, antiBlackness operated through colonial attitudes to reduce Black women to breeders valuable only for the children they produced. As such, their children were reduced to property, which could be bought and sold, as their mothers had no claim over them. Clearly, colonial attitudes necessarily relied on gender.

It can be argued that by having a funding structure that is tied to open cases, the Ministry of Children and Youth Services is perpetuating this history and colonial attitudes. Specifically, there is still monetary value in Black children, as CAS benefits from opening cases against hyper-surveyed Black families. Such children are often removed from their mothers through 
tools, like risk assessment, which work to construct Black women as poor mothers, suggesting that they cannot occupy such a role. In reducing, or eliminating parental rights, Black women may still be reduced to 'breeders' instead of mothers. This works with the Child, Youth and Family Services Act (2017) to perpetuate anti-Blackness because the harm from this kind of removal is not built into the definition of harm offered in the Child, Youth and Family Services Act (2017).

Furthermore, funding can limit conversations about anti-Black racism. Specifically, Participant 2 noted that schools are the primary referral source. He later went onto say that if workers want to close a file, it is

teachers unfortunately, who will push back and say, you know, we shouldn't be closing the file, we should stay open. Um, but then when you ask them why, they can't really outline their concern, they just have, uh, an instinctual feeling of whatever the child, right? of, of, what they're seeing with the child and, and especially if they don't have a good relationship with the, with the, um... with the parents, um, that's where we get the pushback of, of feeling like we need to do more or we need to be more involved when we're trying to be the least intrusive... Thus, faculty at schools may hold racial bias and prejudice that have not been examined. Therefore, anti-Black racism exists in schools too. This suggests that CAS may have a responsibility to ensure that conversations about anti-Black racism are also occurring with community partners, like schools.

Unfortunately, they may not feel comfortable doing so if schools referrals lead to open cases from which funding is derived. This was supported by Participant 2 when he said that even when senior managers know calls may not have a valid basis to them, it's not in the best interest 
of the Society to turn them away. If senior managers are doing this, workers may not feel comfortable doing anything that will deter referrals either on a large scale, including advocating for conversations about anti-Black racism that extend beyond CAS and into the other community partners that they work closely with. 


\section{Chapter VII: Implications}

While the Ontario Association of Children's Aid Societies' (2016) report, One Vision, One Voice, and the Government of Ontario's (2017) Anti-Black Racism Strategy call for training on anti-Black racism to occur, interviews with participants reveal that conversations about antiBlack racism need to go much deeper than training and must occur agency wide at multiple, interrelated levels. Such conversations must include looking at how CAS' funding structure perpetuates anti-Blackness. Thus, participant voices reveal that the funding structure of CAS needs to be reconsidered so that CAS does not receive funding for opening and investigating cases. Funding should be given to provide resources and supports to communities and parents, to keep families together and prevent their initial contact with CAS to begin with, especially for Black families.

Furthermore conversations about anti-Black racism need to also include the Child, Youth, and Family Services Act (2017). Specifically, social workers need to think about whose definition of safety is entrenched in the Child, Youth, and Family Services Act (2017). While there is no denying that physical, sexual and emotional abuse of a child constitutes harm, the impact of anti-Black racism perpetuated by child welfare workers must also be a serious consideration when defining harm to youth. This is needed to deconstruct welfare workers as exalted subjects.

While conversations about anti-Black racism need to include funding and the Child, Youth and Family Services Act (2017), interviews with participants suggest that if the definition of harm were altered to include anti-Black racism, it would be easier to have conversation about anti-Black racism at CAS, as it would be built into the work done. Risk assessment tools need to exist to also make workers pause to also consider their own bias, social location, how they may 
perpetuate anti-Black racism and how this may be harmful too. This would help to ensure that conversations about anti-Black racism do not solely happen when specific time and space for such conversations exist. This is important because workers highlighted that their work can be fast-paced, unpredictable and filled with lots of paperwork. As such, the language used on a daily basis needs to be more critical and less process oriented.

This reveals that conversations about anti-Black racism must both begin with and include the Child, Youth and Family Services Act (2017). A modified Child, Youth and Family Services Act (2017) may make space for such conversations on a daily and informal basis, as it may be embedded in decision making tools used at the agency. As such, it may mean that more managers at the agency have to be considerate of anti-Black racism and encourage workers to talk about it. This is important because participants talked about the need for upper levels of management at CAS begin to make space for these conversations, especially as Participant 2 talked about the fear of being labeled a 'rogue worker.' At the same time, such conversations may need to occur before changes to the Child, Youth and Family Service Act (2017) are made. This reveals that beginning to address and talk about anti-Black racism at CAS is complex and must be a process, rather than simply training that occurs during specific times for frontline staff.

Both Participant 2 and Participant 3 seemed to acknowledge that frontline workers have a role to play in making these conversations more prominent. Participant 3 said that it would be that if we are able to have open conversations within the Society from, you know, from frontline all the way to CEO, you hope that then, as an organization, the CEO could go to like let's say OACAS right, the big [inaudible] child protection board and say to them, you know, these are the issues of how we're set up ...this is how they're impacting, you know, people of colour and 
going back to them and advocating for changes in how the system works, right.

That ultimately would be the big thing, but yeah, that's not what it is right now.

Further to that, Participant 3 said that "I just feel like it has to start like the top-down but if it's not going to, the flipside would be, you know, it has to start within amongst the workers." Because participants have already noted that they feel like the upper/senior management may act as a barrier to initiating conversations about anti-Black racism, they may only be able to take the lead on initiating these conversations if they can seek allies outside the agency who may be able to assist them if they face resistance from senior managers. An example of such an ally may be Chief Commissioner of the Ontario Human Rights Commission, Renu Mandhane, who has called for the collection and release of race-based statistics for all Children's Aid Societies. Other examples of allies may be members of the steering committee of One Vision One, One Voice, such as those from the Black Community Action Network.

Furthermore, the remarks made by participants also suggest that within CAS policy, it must be explicitly stated that workers will not face a threat of job loss, or repercussions in any form in the workplace. This may guide the responses of managers when anti-Black racism is brought up by frontline workers. Similarly, CAS could implement some degree of oversight of managerial responses when frontline employees try to initiate conversations. In such a process, frontline workers should have the option of remaining anonymous so they do not feel like they are being surveyed in any way. While implementing changes to the funding structure and the Child, Youth and Family Services Act (2017) may be a big, lengthy process, changes to CAS policy may be easier to achieve in a shorter timeframe and may act as a good starting point for beginning to break down a significant barrier identified by participants. 
Additionally, while CAS has consulted with self-identified members of Black communities to write strategies and reports, like One Vision, One Voice and Toronto Action Plan to Confront Anti-Black Racism, participant remarks reveal that members from Black communities must further be consulted to change how limited the conversations about anti-Black racism are. This is supported by Participant 3 who noted that with CAS I think that just like, like they're the expert, but they need to defer to the experts on this. There's a huge group of folks at the City, Black folks and community leaders that came together to set the pace of that strategy that they're using, so why on earth the Children's Aid Societies bringing in training from those people?

Therefore, members of Black communities who are experts in anti-Black racism should be consulted to define topics significant when talking about anti-Black racism in child welfare and to deepen the level of conversation currently happening. This may be especially important because Participant 1 talked about how conversations at branch meetings are 'brief.' This implication is particularly important given that anti-Black racism also means resistance to the oppression felt by Black peoples. Anti- Black racism has a strong connection to community organizing and Black radicalism and indeed means that Black peoples are leaders in creating change against the specific kinds of oppressions they face.

While these implications suggest that fairly big changes need to happen at CAS, Participant 3 pointed to the fact that CAS has successfully made also a lot of changes for other populations, such as the LGBTQ communities and women who have experienced violence. Specifically, she noted that 
when they [CAS] talked about things in the LGBTQ community, or like they'd go through a violence against women, there was whole protocol that was developed through a committee given to all the workers so those things are possible. The same thing should apply to working with our Black families particularly when the majority of our families, if you look, at like citywide are Black.

Therefore, broad change is possible, as evidenced by how CAS has responded to other marginalized population.

Other implications are related to social work education, itself. Specifically, the study raises questions about how schools of social work can educate about, not just issues of systemic racism, but systemic anti-Black racism. For example, as social workers, we are educated about various acts that govern the work that we do, but are seldom taught to question them. It is often taught that social workers must follow them in order to be a "good" social worker, even when they may actually stem from or perpetuate anti-Black racism. Thus, they come to be seen as deeply connected to standards for professional practice in the field of social work. This is true for the Child, Youth and Family Services Act (2017), which defines abuse and mandates that child abuse be reported.

Unfortunately, as social workers, we are very rarely taught about where the Child, Youth and Family Services Act (2017) comes from. More specifically, we are rarely taught to consider how and who creates such acts, or who makes up the corresponding ministry, like the Ministry of Children and Youth Services. We are rarely taught the history behind such acts and how such acts have evolved and changed over time. This discourages students from interrogating the act to analyze how it may perpetuate and develop from anti-Black racism. For example, social work 
students may not ever question why one definition of harm is entrenched in the Child, Youth and Family Services Act (2017) and it may, instead, be viewed objectively. In this way, social work education may also be responsible for perpetuating "white liability."

Therefore, schools of social work need to encourage the interrogation of legislation and ministries that govern social work, including the College of Social Workers who also assist in ensuring workers adhere to such legislation by having social workers register with them. This enables whiteness to be exposed and asks social work students to think more critically about how these acts can inform the work that they do in the field as it relates to the spread of anti-Black racism. In general, schools of social work could have courses that include a deeper focus on antiBlack racism, and an interrogation of the definition of professionalism within the social work field as they relate to such acts and ministries. Furthermore, schools of social work could also talk about Black radicalism and how anti-Black racism is also about resistance. There could be a deeper focus on Garveyism and Afrocentrism, as political ideologies, to help social work students understand how they have informed anti-Black racism. 


\section{Chapter VIII: Conclusion}

Ultimately, conversations about anti-Black racism are so significant because the can serve as a starting point for reducing the amount of Black children in-care. Indeed this was also reflected in the comments of Participant 2, as they noted that these conversations would begin to reduce Black children in-care by reducing contact with Black families altogether. Reports like One Vision One Voice and the Government of Ontario's Anti-Black Racism Strategy acknowledge that anti-Black racism exists at CAS. Further, they acknowledge that we must work to address anti-Black racism.

While this is a great step in the right direction, there is more that needs to be done. As I spoke with participants it became clear that they do their best apply a critical lens when working with families, but there are multiple barriers that prevent these conversations from occurring pervasively. Indeed it was disappointing to hear Participant 2 speak of workers being fearful of being labeled 'rogue' or a 'problem' and, as such, fear losing their livelihood for initiating conversations. Findings from participants reveal how deeply anti-Black racism is engrained in child welfare, ultimately limiting conversations about this important topic from being critically and meaningfully embedded into the work that is done at CAS.

As such, I hope this MRP makes space for thinking about how conversations around this topic can be more critical and how we can begin breaking down barriers. I hope that it disrupts and challenges CAS, making more space for members from Black communities to continue to talk about how best to address anti-Black racism and to further shape the way such conversations take place and what they should include. 


\section{Appendix A \\ Ryerson University \\ Consent Agreement}

You are being invited to participate in a research study. Please read this consent form so that you understand what your participation will involve. Before you consent to participate, please ask any questions to be sure you understand what your participation will involve.

ANTI-BLACK RACISM IN THE CHILD WELFARE SYSTEM: HOW DO CRITICAL SOCIAL WORKERS BRING IT UP?

INVESTIGATORS: This research study is being conducted by Ruth Damdar, an MSW student at Ryerson. It will be supervised by Jennifer Poole, MSW, PhD, graduate director and associate professor at the School of Social Work at Ryerson University.

If you have any questions or concerns about the research, please feel free to contact Ruth

Damdar at rdamdar@ ryerson.ca

PURPOSE OF THE STUDY: The study is designed to explore how self-identified critical frontline workers, or frontline workers who are familiar with Anti-Oppressive Practice, AntiBlack Racism, Critical Race Theory or other critical approaches to critical social work at the Children's Aid Societies carry out conversations of Anti-Black Racism, and how such conversations may impact racism in the child welfare system generally. Approximately 3-5 participants will be recruited for this study. To be eligible, one must be a frontline worker in the child welfare system either currently or recently within the last 2 years. Further, to be eligible participants must self-identify as a critical frontline worker, or as a frontline worker who is familiar with Anti-Oppressive Practice, Anti-Black Racism, Critical Race Theory or other critical approaches to critical social work. The results will be included in the Major Research Paper of graduate student, Ruth Damdar, which is a requirement needed to complete the MSW degree at Ryerson.

WHAT YOU WILL BE ASKED TO DO: If you volunteer to participate in this study, you will be asked to do the following things:

- Participate in an interview

- Provide information by answering questions related to your experience as a frontline worker in the child welfare system. Examples of questions include: How do critical frontline workers, such as yourself, have conversations about anti-Black racism at work? How do these conversations impact the work that you do?

- The interview should not be longer than 90 minutes.

- Answer follow-up questions that may arise after the interview, potentially via e-mail

- You can withdraw from this study at any point without penalty

- Following this interview, you can withdraw information that you have provided. There will be no consequences for doing so and your information will be erased immediately.

- After your participation, you can contact Ruth Damdar at rdamdar@ ryerson.ca for any follow-up question you may have 
- Research findings will be available to participants through Ryerson University's Master of Social Work website.

\section{POTENTIAL BENEFITS:}

Participants will be able to have their experiences and opinions heard, and confidentially shared, as it relates to their views about Anti-Black Racism in the child welfare system. I cannot guarantee, however, that you will receive any benefits from participating in this study. WHAT ARE THE POTENTIAL RISKS TO YOU AS A PARTICIPANT

Potential risks are low, but do exist. Such risks include: psychological risks, as participants may feel upset around the topic; social risks of being excluded or reprimanded at work; a risk of participants being identified; financial risk due to the risk of job loss. The researcher will take the necessary steps to address such risks, including keeping participant identity confidential through the use of codes or pseudonyms. Additionally, the specific name and location of each Children's Aid Society will not be used. Instead, they will be referred to as Children's Aid Societies. Participants always have the right to skip questions, withdraw answers, or withdraw from the research altogether.

\section{CONFIDENTIALITY:}

Confidentiality will be maintained in the following ways. Only the researcher and the supervisor will have access to research, and audio-recordings. The research transcripts will be stored on an encrypted USB device. The audio-recordings may be stored on a password-protected device, or, alternatively an encrypted USB device kept in a locked drawer at the residence of the primary researcher. Audio-recordings will be transcribed as soon as possible and then erased.

Transcriptions will be stored on an encrypted USB that will be kept in a locked drawer at the primary investigators place of residence. If participants wish to verify their transcripts, they may email me and I will send them their transcripts over email. They may do this, request changes, or withdraw their data completely at any point. Their requests will be honoured. The consent form will be stored in a locked cabinet at the School of Social Work in the office of Major Research Supervisor, Jennifer Poole. Participant identity will be kept confidential through the use of codes or pseudonyms. Additionally, the specific name and location of each Children's Aid Society will not be used. Instead, they will be referred to as Children's Aid Societies. Participants always have the right to skip questions, or withdraw answers. Withdrawn answers will not be used and will be deleted. The participant may choose to withdraw from the study altogether. If the participant chooses to do so, data will be deleted and information will not be used in the study. Participants will still receive incentives.

\section{INCENTIVES FOR PARTICIPATION:}

Incentives will be offered as a way to thank participants for their time. The incentive will be a $\$ 10$ dollar Starbucks gift card. Participants who choose to withdraw from the study will still receive the incentive.

\section{VOLUNTARY PARTICIPATION AND WITHDRAWAL:}

Participation in this research study is entirely voluntary. You can choose whether or not you would like to participate in this study. You can choose to skip questions and you may choose to stop participating in this study at any time. If you choose to stop participating, you may also choose to withdraw your answers from being included in this study and your information will be deleted. You can view your own transcripts at any point and may choose to have some or all of your data removed. If you choose to stop participating, you will still receive incentives. Whether 
or not you decide to participate in this study will not influence future relations with Ryerson University or the primary investigator, Ruth Damdar and, the research supervisor, Jennifer Poole, MSW, PhD.

QUESTIONS ABOUT THE STUDY: If you have any questions about the research now, please ask. If you have questions later about the research, you may contact:

Ruth Damdar, MSW student, at rdamdar@ryerson.ca

OR

Major Research Paper Supervisor: Jennifer Poole, MSW, PhD

Associate Director, Graduate Program; Associate Professor

School of Social Work

Ryerson University

350 Victoria Street

Toronto, Ontario

Canada M5B 2K3

Tel. (416) 979-5000 ext. 6253

Email: jpoole@ryerson.ca

This study has been reviewed by the Ryerson University Research Ethics Board. If you have questions regarding your rights as a participant in this study please contact:

Research Ethics Board

c/o Office of the Vice President, Research and Innovation

Ryerson University

350 Victoria Street

Toronto, ON M5B 2K3

416-979-5042

rebchair@ryerson.ca 


\section{ANTI-BLACK RACISM IN THE CHILD WELFARE SYSTEM: HOW DO CRITICAL SOCIAL WORKERS BRING IT UP? \\ CONFIRMATION OF AGREEMENT:}

Your signature below indicates that you have read the information in this agreement and have had a chance to ask any questions you have about the study. Your signature also indicates that you agree to participate in the study and have been told that you can change your mind and withdraw your consent to participate at any time. You have been given a copy of this agreement. You have been told that by signing this consent agreement you are not giving up any of your legal rights.

Name of Participant (please print)

Signature of Participant $\quad \overline{\text { Date }}$

I agree to be audio-recorded for the purposes of this study. I understand how these recordings will be stored and destroyed.

Signature of Participant

Signature of Primary Investigator
Date

Date 


\section{Appendix B: Recruitment Flyer \\ Participants Needed for Research Study \\ Anti-Black Racism In The Child Welfare System: How Do Critical Social Workers Bring It Up?}

If you: self-identify as a critical frontline worker, or as a frontline worker who is familiar with Anti-Oppressive Practice, Anti-Black Racism, Critical Race Theory or other critical approaches to critical social work; and if you are currently employed Children's Aid, or if you were employed at Children's Aid within the last 2 years then you are invited to participate in this study.

This is a qualitative study being conducted by Ruth Damdar, an MSW student at Ryerson University and supervised by Jennifer Poole, MSW, PhD. The study focuses on racism in the child welfare system as it relates to the overrepresentation of Black youth in care. Specifically, the study asks how self-identified critical frontline workers carry out conversations of Anti-Black Racism at Children's Aid.

Potential participants may choose to participate in an interview that is not expected to last more than 90 minutes. Interviews will take place at the convenience of the participant either in-person or via Skype. Your identity will be kept confidential and the location of the agency will not be specified. Consent forms will be provided ahead of time for your review.

In appreciation of your time, a $\$ 10$ Starbucks gift card will be provided to you.

Participants have the right to withdraw from the study at any point and their information will not be used in the study and will be deleted. Audio-recordings will be transcribed as soon as possible and then erased. Audio-recordings will be stored on a password protected, or encrypted device, stored in a locked drawer at the primary researcher's residence. Transcriptions will be stored on an encrypted USB that will be kept in a locked drawer at the primary investigators place of residence. If participants wish to verify their transcripts, they may email me and I will send them their transcripts over email. Participants may do this, request changes, or withdraw their data completely at any point. These requests will be honoured. If participants withdraw, they will still receive incentives. The research findings will be included in the Major Research Paper, a requirement for the completion of the MSW degree at Ryerson University. If you are interested in learning more, please contact: Ruth Damdar, MSW student, at rdamdar@ryerson.ca.

*This research study has been reviewed and approved by the Ryerson University Research Ethics Board 
Appendix C: Recruitment Facebook Post

\section{Participants Needed for Research Study Anti-Black Racism In The Child Welfare System: How Do Critical Social Workers Bring It Up?}

Participants are needed for a research study on racism in the child welfare system. Specifically needed are frontline workers who are currently employed at Children's Aid or who were employed there within the last 2 years. To be eligible, potential participants must also selfidentify as critical frontline workers, or as frontline workers who are familiar with AntiOppressive Practice, Anti-Black Racism, Critical Race Theory or other critical approaches to critical social work. If you know anyone who may be interested in participating, please pass on this information to them. The details are as follows: This is a qualitative oral history narrative study being conducted by Ruth Damdar, an MSW student at Ryerson University and supervised by Jennifer Poole, MSW, PhD. The study focuses on Anti-Black Racism in the child welfare system as it relates to the overrepresentation of Black youth in care. Specifically, the study asks how self-identified critical frontline workers carry out conversations about Anti-Black Racism at Children's Aid. Potential participants may choose to participate in an interview that is not expected to last more than one hour. Interviews will take place at the convenience of the participant either in-person or via Skype. Your identity will be kept confidential and the location of the agency will not be specified. Consent forms will be provided ahead of time for your review. Incentives will be provided to thank participants for their time. The incentive will be a $\$ 10$ Starbucks gift card. Participants have the right to withdraw from the study at any point and their information will not be used in the study and deleted. Audio-recordings will be transcribed as soon as possible and then erased. Audio-recordings will be kept on a password protected or encrypted device, stored in a locked drawer at the primary researcher's place of residence. Transcriptions will be stored on an encrypted device that will be kept in a locked drawer at the primary investigators place of residence. If participants wish to verify their transcripts, they may email me and I will send them their transcripts over email. Participants may do this, request changes, or withdraw their data completely at any point. These requests will be honoured. If participants withdraw, they will still receive incentives. The research findings will be included in the Major Research Paper, a requirement for the completion of the MSW degree at Ryerson University. If you are interested in learning more, please contact Ruth Damdar, MSW student, at rdamdar@ryerson.ca, or by sending a private message to this private Facebook page. If you are interested, please do not post publically on the Facebook page.

* This research study has been reviewed and approved by the Ryerson University Research Ethics Board 
Appendix D: Interview Questions

Research Questions

1. Why did you decide to participate in this study?

1. Do you self-identify as new at the agency? What does a typical day at work look like for you? What does being a critical worker mean to you? What is it like to be a critical worker in such a workplace?

2. Tell me about how critical frontline workers, such as yourself, have/start/continue conversations about Anti-Black Racism at work? Is there anything in particular that influences how you carry out these conversations?

3. What are the responses when you try to have these conversations? How do your coworkers, managers and other react?

4. How do the conversations, or the lack of conversations around Anti-Black Racism impact the work that you do? The work environment? The field? You personally?

5. What needs to happen to create more space for work around Anti-Black Racism at Children's Aid Society? How could this affect the overrepresentation of Black youth in care?

6. Is there anything else I should know? 


\section{Appendix E: Data Collection}

\section{Demographic Questions}

1. Name:

2. Which Children's Aid Society do you work for?

3. Do you self-identify as a new worker at the agency?

4. Please provide your email address:

5. Do you identify as racialized? 
Appendix F

\section{List of Counseling Resources}

1. Family Services Toronto (Free Walk-in single counselling session on Wednesdays; sliding scale: multiple locations)

Address: 128 Sterling Rd Suite 202, Toronto, ON M6P 0A1

Phone Number: (416) 595-9230

Website: https://familyservicetoronto.org

2. Bennett Counselling Services

Address: 3621 Hwy 7 \#307, Markham, ON L3R 0G6

Phone Number: (416) 720-8586

Website: http://www.bennettcounselling.com

3. Rexdale Community Health Centre (Mon-Friday 9-5)

Address: 8 Taber Rd, Etobicoke, ON M9W 3A4

Phone Number: (416) 744-0066

Website: https://www.rexdalechc.com

4. Across Boundaries- An Ethnoracial Mental Health Centre (North York)

Address: 51 Clarkson Ave, York, ON M6E 2T5

Phone Number: (416) 787-3007

Website: http://www.acrossboundaries.ca 


\section{$\underline{\text { References }}$}

Anyon, Y. (2010). Reducing racial disparities and disproportionalities in the child welfare system: Policy perspectives about how to serve the best interests of African American youth. Children and Youth Services Review, 33, 242-253.

doi:10.1016/j.childyouth.2010.09.007

Baines, D. (2007). Anti-oppressive social work practice. In D. Baines (Ed.) Doing antioppressive practice: Building transformative politicized social work. Halifax: Fernwood.

Benjamin, A, L. (2003). The Black/Jamaican criminal: The making of ideology. Doctoral

Dissertation. Toronto: OISE/University of Toronto.

Benjamin, A., 2002. The social and legal banishment of anti-racism: a black perspective. In:

Chan, W., Mirchandani, K. (Eds.), Crimes of Colour: Racialization and the Criminal Justice System in Canada (pp. 177-190). Toronto: Broadview Press.

Black African Canadian Committee. (2015). Community Consultations: Purpose, Findings and Recommendations. Retrieved from http://www.torontocas.ca/sites/torontocas/files/CAST_CommConsultRecommendationsMay2 016.pdf

Bouma, G., Ling, R., \& Wilkinson, L. (2017). The research process. Toronto: Oxford University Press.

Boyd, R. (2013). African American disproportionality and disparity in child welfare: Toward a comprehensive conceptual framework. Children and Youth Services Review, 37, 15-27. http://dx.doi.org/10.1016/j.childyouth.2013.11.013.

Cech, M. (2010). Interventions with children and youth in Canada. Don Mills: Oxford University Press. 
Children's Aid Society of Toronto. (2017). Annual Report 2016-2017. Retrieved from http://torontocas.ca/sites/torontocas/files/AnnualReports/AR2016-17_Eng.pdf

Chilisa, B. (2012). Decolonizing the interview method. Research methods in question. Indigenous research methodologies,(pp. 73-96). Los Angeles, CA: Sage Publications.

Childers-Mckee, D. C., \& Hytten, K. (2015). Critical race feminism and the complex challenges of educational reform. Urban Rev, 47, 393-412. DOI 10.1007/s11256-015-0323-z.

Child, Youth and Family Services Act, 2017, S.O. 2017, c. 14, Sched. 1

Clarke, J. (2012). Beyond child protection: Afro-Caribbean service users of child welfare. Journal of Progressive Human Services, 23(3), 223-257.DOI:10.1080/10428232.2012.719119

Clarke, J. (2011). The challenges of child welfare involvement for Afro-Caribbean families in Toronto. Children and Youth Services Review, 33(2), 274-283.

DOI:0.1016/j.childyouth.2010.09.010

Clarke, J., Minster, M. S., \& Gudge, L. (2018). Private numbers, private pain: What is hidden behind the disproportionate removal of Black children and youth from families by Ontario child welfare? In P. Soheila, N. Khanlou \& J. Clarke. (Eds.), Today's youth and mental health (pp. 187-209). Cham: Springer International Publishing

Clarke, J., Pon, G., Benjamin, A., \& Bailey, A. (2015). Ethnicity, race, oppression, and social work: The Canadian case. International Encyclopedia of the Social \& Behavioural Sciences, 8. Retrieved from http://dx.doi.org/10.1016/B978-0-08-097086-8.28107-5

Contenta, S., Monsebraaten, L., \& Rankin, J. (2014). Why are so many children in foster and group homes? The Toronto Star. Retrieved from http://www.thestar.com/news/canada/2014/12/11/why_are_so_many_black_children_in_fost er_and_group_homes.html 
Creswell, W.J., \& Poth, N.C. (2017). Qualitative inquiry and research design: Choosing among five approaches (Fourth Edition). Thousand Oaks,CA: Sage Publications

Cross, T. L. (2008). Disproportionality in child welfare. Child Welfare, 87(2), 11-22. Retrieved from https://search-proquest-com.ezproxy.lib.ryerson.ca/docview/213807712?pqorigsite $=$ summon

Darlington, Y., Osmond, J., \& Peile, C. (2002). Child welfare workers' use of theory in working with physical child abuse: Implications for professional supervision. Families in Society: The Journal of Contemporary Human Services, 83(1) 54-63. Retrieved from https://search-proquest-com.ezproxy.lib.ryerson.ca/docview/230170316?pq-origsite=summon

Deliovsky. K. (2017). Whiteness in the qualitative research setting: Critical scepticism, radical reflexivity and anti-racist feminism. Journal of Critical Race Theory, 4(1), 1-24. Retreived from https://ojs.library.queensu.ca/index.php/CRI/article/view/6369/6133

Deliovsky, K., \& Kitossa, T. (2013). Beyond Black and white: When going beyond may take us out of bounds. Black Studies, 44(2), 158-181. DOI: 10.1177/0021934712471533

Dumbrill, G. (2006). Parental experience of child protection intervention: A qualitative study. Child Abuse \& Neglect, 30, 27-37. Retrieved from https://pdfs.semanticscholar.org/cf59/303c721f4a5a17bb11e42d601a2810e84b6f.pdf

Eburne, P, J. (2014). Garveyism and its involutions. African American Review, 47(1).1-19 Retrieved from https://www.jstor.org/stable/24589792

Frankenberg, R. (1993). White women, race matters: The social construction of whiteness. Minnesota: University of Minnesota Press.

Freymond, C., \& Cameron, G. (2011). Child welfare interventions that make sense to mothers. In K. Kufeldt \& B. Mckenzie (Eds.), Child welfare: Connecting research, policy and 
practice (pp.131-143). Waterloo: Wilfrid Laurier University Press.

Gosine, K., \& Pon, G. (2011). On the front lines: The voices and experiences of racialized child welfare workers in Toronto, Canada. Journal of Progressive Human Services, 22(2), 135-159. DOI: 10.1080/10428232.2011.599280

Government of Ontario. (2017). Anti-Black Racism Strategy. Retrieved from https://www.ontario.ca/page/ontarios-anti-black-racism-strategy

Harris, P., A. (2012). Critical race theory. International Encyclopedia of the Social \& Behavioural Sciences. Retrieved from https://works.bepress.com/angela_harris/17/

Hick, S. (2009). Social Work in Canada: An Introduction $3^{\text {rd }}$ Edition. Toronto: Thompson Educational Publishing.

Hoskins, M., \& White, J. (2009). Processes of discernment when considering issues of neglect in child protection practice. Child and Youth Care Forum, 39, 27-45. DOI 10.1007/s 10566-009-9089-3

Jonson-Reid, M., Drake, B., \& Zhou, P. (2013). Neglect subtypes, race, and poverty: Individual, family and service characteristic. Child Maltreat, 18(1), 30-41. doi:10.1177/1077559512462452.

Kumsa, K. M., Mfoafo- Mcarthy, M., Obaba,F., \& Gaasim, S. (2014). The contours of antiBlack racism: Engaging anti-oppression from embodied spaces. Journal of Critical AntiOppressive Social Inquiry, 1(1). 21-38. https://exchange.youthrex.com/system/files.../file.../6-10-1-SM\%20\%281\%29.pdf?..

Ladson-Billings, G. (2000). Racialized discourses and ethnic epistemologies. In N.K. Denzin \& Y.S. Lincoln (Eds.), Handbook of qualitative research (pp. 257-277). Thousand Oaks, California: Sage Publications. 
Lewis, S. (1992, June 9). Report of the advisor on race relations to the Premier of Ontario, Bob Rae. Retrieved from www.siu.on.ca/pdfs/report_of_the_advisor_on_race_relations_to_the_premier_of_ontario_b ob_rae.pdf

Maiter, S., Palmer, S., \& Manji S. (2006). Strengthening social worker-client relationships in child protective services: Addressing power imbalances and ruptured relationships. Qualitative Social Work, 5(2), 167-186. doiorg.ezproxy.lib.ryerson.ca/10.1177/1473325006064255

Maiter, S., Stalker C., \& Alaggia, R. (2009). The experiences of minority immigrant families receiving child welfare services: seeking to understand how to reduce risk and increase protective factors. Families in Society: The Journal of Contemporary Social Services, 90 (1), 26-36. doi-org.ezproxy.lib.ryerson.ca/10.1606/1044-3894.3842

McKenzie-Mohr, S., \& Lafrance, M, N. (2017). Narrative resistance in social work research and practice: Counter-storying in the pursuit of social justice. Qualitative Social Work, 16(2), 189-205. DOI: 10.1177/1473325016657866.

Miller, K., Cahn, K., \& Orellana, R. (2012). Dynamics that contribute to racial disproportionality and disparity: Perspectives from child welfare professionals, community partners, and families. Children and Youth Services Review, 34, 2201-2207.

http://dx.doi.org/10.1016/j.childyouth.2012.07.022

Ministry of Children and Youth Services. (2016). Ontario Child Protection Tools Manual. A Companion to the Ontario Child Protection Standards. Retrieved from www.children.gov.on.ca/htdocs/.../childrensaid/Child-Protection-Standards-2016.pdf 
Mullings, D., \& Mullings-Lewis, R. (2013). How Black mothers 'successfully' raise children in the 'hostile' Canadian climate. Journal of the Motherhood Initative, 4(2), 105-119. Retrieved from https://jarm.journals.yorku.ca/index.php/jarm/article/view/37832/34298

Myers, S. L. (2010). Responses to research synthesis on child welfare disproportionality and Disparities. In Disparities and disproportionality in child welfare: Analysis of the research (chapter 2). Retrieved from http://www.aecf.org/resources/disparities-anddisproportionality-in-child-welfare/

Ontario Association of Children's Aid Societies. (2016). One Vision, One Voice: Changing the Ontario Child Welfare System to Better Service African Canadians Part 2. Retrieved from https://www.scribd.com/document/325822930/One-Vision-One-Voice-Part-2

Pelton, L., H. (1978). Child abuse and neglect: The myth of classlessness. In American Journal of Orthopsychiatry, 48(4), 608-617. Retrieved from https://search-proquestcom.ezproxy.lib.ryerson.ca/docview/1306625810?pq-origsite=summon

Philips, D., \& Pon, G. (2018). Anti-Black racism, bio-power, and governmentality: deconstructing the suffering of Black families involved with child welfare. Journal of Law and Social Policy, 28, 81-100. Retrieved from http://digitalcommons.osgoode.yorku.ca/jlsp/vol28/iss 1/5

Pon, G. (2009). Cultural competency as new racism: An ontology of forgetting. Journal of Progressive Human Services, 20, 59-71. DOI: 10.1080/10428230902871173.

Pon, G., Giwa, S. \& Razack, N. (2016). Foundations of anti-racist/anti-oppressive social work practice. In Al-Krenin and Graham, J. (Eds.), Diversity and social work in Canada (pp. 3858). Don Mills, ON: Oxford University Press.

Pon, G., Gosine, K., and Phillips, D. (2011). Immediate response: addressing anti-native and 
anti-black racism in child welfare. International Journal of Child, Youth and Family

Studies, 3 \& 4. Retrieved from

http://journals.uvic.ca/index.php/ijcyfs/article/view/7763/2554

Pon, G., Phillips, D., Clarke, J., and Abdillahi, I. (2017). Who's protecting whom? In Doing anti-oppressive practice: Social justice social work. Halifax, NS: Fernwood Publishing.

Poole, J. (2010). Progressive until graduation? Helping BSW students hold onto anti-oppressive and critical social work practices. Critical Social Work, 11(2), 1-11. Retrieved from http://www.uwindsor.ca/criticalsocialwork/progressivehold-onto-anti-oppressive-and-critical progressive-until-graduation-helpingcritical-social-work\#top

Razack, S. (2005). How is white supremacy embodied? Sexualized racial violence at Abu Ghraib. Resources for Feminist Research, 32(3-4), 241. Retrieved from http://go.galegroup.com.ezproxy.lib.ryerson.ca/ps/i.do?p=AONE\&u=rpu_main\&id=GALE|A $\underline{184429302 \& v=2.1 \& \mathrm{it}=\mathrm{r} \& \text { sid=summon }}$

Razack, S., Smith, M., and Thobani, S. (2010). States of race: Critical race feminism for the $21^{\text {st }}$ century. Toronto: Between the Lines.

Roberts, B. (2002). Shattered bonds. New York, NY: Basic Civitas Books.

Spivak, G., 1990. The Post-colonial critic: Interviews, strategies, dialogue. New York: Routledge.

Thobani, S. (2007). Exalted subjects: Studies in the making of race and nation in Canada. Toronto: University of Toronto Press.

Wulczyn, F., Gibbons, R., Snowden, L. and Lery, B. (2013). Poverty, social disadvantage, and the black/white placement gap. Children and Youth Services Review, 35(1), 65-74. DOI: 10.1016/j.childyouth.2012.10.005 
Wulczyn, F., \& Lery, B. (2007). Racial disparity in foster care admissions. Retrieved from citizenreviewpanelsny.org/documents/chapin_hall_document.pdf

Yee, Y. J., Hackbusch, C., \& Wong, H. (2015). An anti-oppression (AO) framework for child welfare in Ontario, Canada: Possibilities for systemic change. British Journal of Social Work, 45, 474-492. DOI:10.1093/bjsw/bct141. 